\title{
River Systems and Environmental Change
}

\section{Citation for published version (APA):}

Woodward, J. C., \& Macklin, M. G. (2009). River Systems and Environmental Change. In The Physical Geography of the Mediterranean (1st ed., pp. 319-352). Oxford University Press.

\section{Published in:}

The Physical Geography of the Mediterranean

\section{Citing this paper}

Please note that where the full-text provided on Manchester Research Explorer is the Author Accepted Manuscript or Proof version this may differ from the final Published version. If citing, it is advised that you check and use the publisher's definitive version.

\section{General rights}

Copyright and moral rights for the publications made accessible in the Research Explorer are retained by the authors and/or other copyright owners and it is a condition of accessing publications that users recognise and abide by the legal requirements associated with these rights.

\section{Takedown policy}

If you believe that this document breaches copyright please refer to the University of Manchester's Takedown Procedures [http://man.ac.uk/04Y6Bo] or contact uml.scholarlycommunications@manchester.ac.uk providing relevant details, so we can investigate your claim.

\section{OPEN ACCESS}




\title{
11 \\ River Systems and Environmental Change
}

\author{
Mark Macklin and Jamie Woodward
}

\section{Introduction}

Linking river behaviour and drainage basin evolution to Quaternary environmental change, most notably the effects of climatic variability, tectonics, and human activity on runoff and sediment delivery, has a long history of research in the Mediterranean areas of Europe, North Africa, and the Near East. This field of research was initially stimulated by the (re)discovery at the beginning of the twentieth century of many Classical Period remains buried by river alluvium; perhaps the best known of which is the site of Olympia in western Greece (Huntington 1910) (Figure 11.1). The widespread evidence for large-scale shifts in river channel positions and the rapid growth of deltas and coastal alluvial plains in historical times (Judson 1963; Raphael 1973; Kraft et al. 1980; and Chapter 13) also provided much impetus for this research. In addition, archaeological investigations carried out soon after the Second World War in Algeria (Gaucher 1947), Italy (Selli 1962), Libya (McBurney and Hey 1955) and Spain (Gigout 1959) resulted in the recovery of large numbers of Palaeolithic stone tools from Pleistocene fluvial deposits. These early examples of what has now become more widely known as 'geoarchaeology' (Davidson and Shackley 1976; Butzer 1977) or 'alluvial archaeology' (Macklin and Needham 1992) were, with their strong interdisciplinary focus, highly innovative and ahead of their time in the way they integrated archaeology, geomorphology, and geochronology.

Building on this theme, the principal aim of this chapter is to consider how river systems in the Mediterranean region have responded to the environmental changes that took place during the Late Quaternary-a time interval corresponding approximately to the last 130,000 years. There are a number of reasons for choosing this period for reviewing river-environment interactions in the Mediterranean:

1. It encompasses the last glacial-interglacial cycle (c.130 to $10 \mathrm{ka}$ ) for which there is now abundant global evidence from polar ice cores, speleothem records, and lake and marine sediments, for both longand short-term changes in climate. These changes included massive reorganizations of the atmosphereocean-cryosphere systems - often over timescales of less than 100 years (Lowe and Walker 1997) — and they are clearly recorded in the Mediterranean region (see Allen et al. 1999 and Chapter 4). These climatic oscillations (characterized by episodes of warm and cold, wet and dry conditions) had major effects on river behaviourboth indirectly, through changes in vegetation cover (one of the primary controls of river basin hydrology and sediment supply) and directly, through changing atmospheric circulation and associated weather systems that give rise to extreme hydrological events, such as floods and droughts (Greenbaum et al. 2006).

2. In the more tectonically active parts of the Mediterranean, such as south-east Spain and much of Greece and Turkey (see Vita-Finzi 1986, and Chapter 1), the Late Quaternary Period is of sufficiently long duration to allow observation of the impact of endogenic processes (including crustal movements and volcanic activity) on river network configuration and rates of channel incision-as well as on long-term patterns of fluvial 


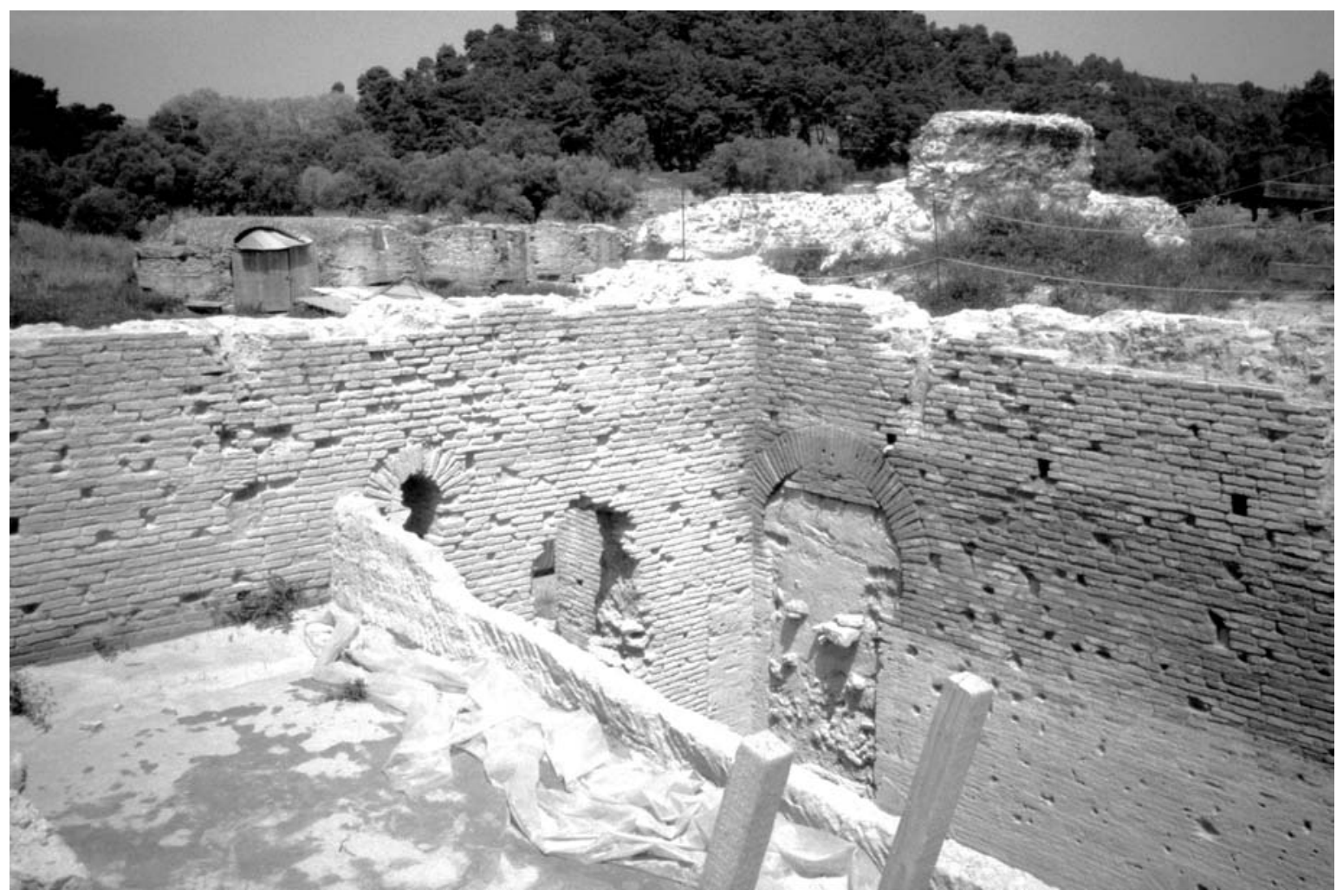

Fig. 11.1. A building under excavation at the archaeological site of Olympia in the valley of the Alfíos River in the western Peleponnese, Greece. This is the ancient site of the Olympic Games and the entire site was buried by alluvium from the Kladeos River which is a small right bank tributary of the Alfíos. The doorway on the right and the room on the left are still filled with alluvium (photo: Jamie Woodward).

sedimentation and storage (Harvey and Wells 1987; Collier et al. 1995; Westaway et al. 2004). Tectonic activity is also an important control on the location and development of badlands as discussed in Chapter 1.

3. This is a key period for the development of our own species. Anatomically modern humans entered Europe for the first time via the eastern Mediterranean around 100,000 years ago and, by about 30 to $25 \mathrm{ka}$, Neanderthals had disappeared from the archaeological record. The long-term dispersal and seasonal subsistence patterns of these early humans were commonly focused on coastal environments and in river valleys. Thus, many important Middle and Upper Palaeolithic sites are found in fluvial settings (e.g. Higgs and Vita-Finzi 1966; Gamble 1986; Bailey 1997) and the reconstruction of Late Quaternary river environments is often key to their interpretation (Pope and van Andel 1984; Bailey et al. 1990; Macklin et al. 1997).
4. The Late Quaternary includes the present Holocene interglacial during which human activity has had an increasing impact on the Mediterranean environment (Chapter 9) including its river systems. Indeed, one of the most challenging and long-standing problems that confronts the study of Holocene river development in the region is how to isolate the effects of human activity on the nature and rate of fluvial erosion and deposition (Vita-Finzi 1969; Butzer 1980; Lewin et al. 1995; Bintliff 2002). Over the past decade or so, this has been a major research focus facilitated by the increasing availability of continuous land- and ocean-based proxy-climate records that document significant Holocene climatic variability in the Mediterranean region extending into the historical period (e.g. Casford et al. 2001; Sadori 2001; Roberts et al. 2001).

5. In order to identify and understand both the processes that govern river behaviour and causality 
relationships in fluvial systems, it is essential that alluvial units are reliably dated. Increasingly robust fluvial geochronologies based on radiometric dating methods such as luminescence and uranium series are now available for a growing number of Mediterranean river basins and these techniques have led to new insights into Middle and Late Pleistocene river behaviour (Macklin et al. 2002; Woodward et al. 2008). In addition, the development of accelerator mass spectrometry has revolutionized the dating of terminal Pleistocene and Holocene age fluvial deposits by the virtue of being able to date very small samples of organic material that could not have been dated using conventional radiocarbon dating methods (Woodward et al. 2001; Thorndycraft and Benito 2006). This has produced a rapidly expanding database of radiometrically dated Late Glacial and Holocene fluvial units that, in conjunction with new high-resolution proxy climate records, have enabled the relationship between river behaviour and climate change to be documented and interrogated in increasing detail over both space and time (e.g. Abbott and Valestro 1995; Woodward et al. 2001; Macklin et al. 2002; Thorndycraft and Benito 2006; Zielhofer et al. 2004).

This chapter is divided into five sections. The first is a review of Mediterranean river systems and related environmental change research that highlights some of the major themes that have emerged over the last five decades or so. The second section presents a new typology of Late Quaternary Mediterranean river development, with particular reference to the tectonic and geological settings of river basins and the effects of Pleistocene environmental change-including glaciation. In this section, Mediterranean river responses to environmental change are examined over the last glacialinterglacial cycle (c.130 to $10 \mathrm{ka}$ ) where the effects of both orbitally driven and millennial-scale climatic variability are evident. The third part of this chapter examines the Holocene record (the last c.11,500 years)—where human impact and climatic oscillations were the key drivers of change within river basins. Fourthly, we examine river behaviour during the last neoglacial cycle (sensu Rumsby and Macklin 1996), which started c.1, 000 years ago and includes the socalled 'Medieval Warm Period' and 'Little Ice Age' (LIA). The final section explores direct human modifications to river channel systems that have been especially prominent over the last 150 years or so and especially in the decades since the Second World War. Chapter 8 focuses on the present-day hydrology, river regimes, and sediment load of Mediterranean catchments and includes a discussion of the implications of the Water Framework Directive for river systems in the European Mediterranean.

\section{Models of Mediterranean Quaternary River Development}

Research conducted on Late Quaternary river histories in the Mediterranean up to the end of the 1960s was carefully reviewed and synthesized by Claudio Vita-Finzi in his acclaimed book, The Mediterranean Valleys: Geological Changes in Historical Times, published in 1969. Vita-Finzi's study was particularly important because it was firmly grounded on almost a decade of fieldwork around the entire Mediterranean basin, extending from south-west Spain to the Jordan Valley and the Dead Sea. Using stone tools, pottery, coins, and other archaeological materials incorporated within alluvial sequences, for dating control, together with a very limited number of radiocarbon dates (five in total), he constructed a correlation scheme for Late Pleistocene (50 to $10 \mathrm{ka}$ ) and historical (post-Roman) alluvial units in the Mediterranean that he termed the 'Older' and 'Younger' Fills, respectively. Figure 11.2a shows a schematic crosssection of a valley in Epirus, north-west Greece where Vita-Finzi worked with the Cambridge archaeologist Eric Higgs in the 1960s (Higgs and Vita-Finzi 1966). This diagram developed from work on the Pleistocene and Holocene alluvial record in the Louros Valley near the Palaeolithic rockshelter site of Asprochaliko and it was instrumental in the development of Vita-Finzi's Mediterranean-wide model published in 1969. It shows a prominent high terrace surface formed in a range of Pleistocene sediments - including strongly-weathered fan sediments or red beds-as well as trunk stream coarse-grained alluvial sediments that commonly interdigitated towards the valley sides with coarse limestone screes. Tufa deposits (Chapter 10) and cemented screes were common in this Older Fill. The historical or Younger Fill is set within the Pleistocene sediments in a narrow valley-floor setting created by Holocene incision and is dominated by fine-grained sediments that show little or no evidence of alteration by weathering. This phase of predominantly fluvial sedimentation has a much less variable sedimentology than the Older Fill and, according to the Vita-Finzi model, it was deposited after the Roman Period following a prolonged phase of early and mid-Holocene incision (Figure 11.2b). The thick deposits of fine-grained alluvium from the Kladeos River, that buried the ancient site of the Olympic Games at Olympia in the lower Alfios Valley of the Peloponnese, 

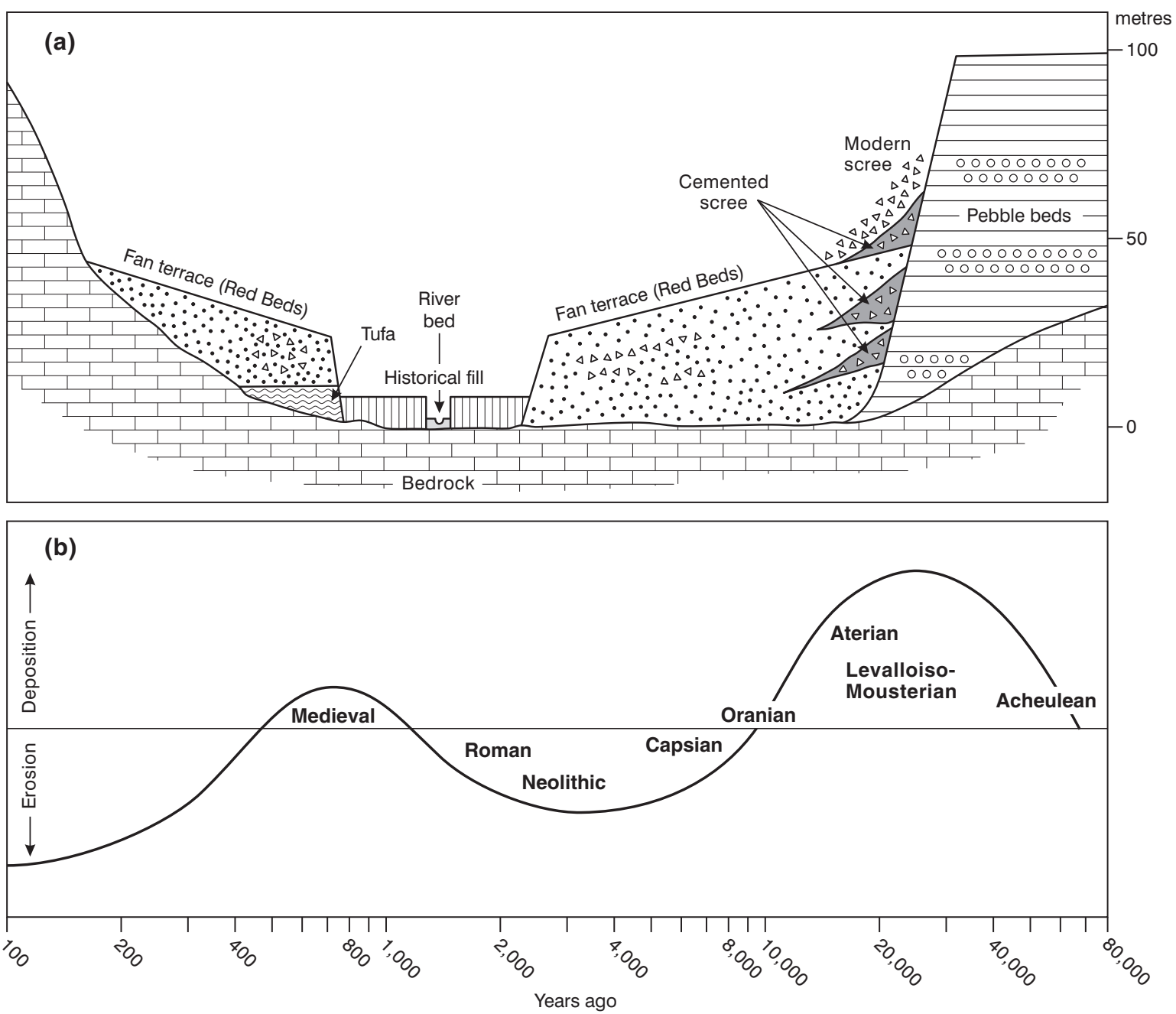

Fig. 11.2. (a) The Quaternary sediments of the Louros Valley in Epirus, north-west Greece (modified from Higgs and Vita-Finzi 1966). The high fan terrace is the surface of the Older Fill. These Pleistocene sediments are commonly strongly weathered and were also referred to as 'Red Beds'. The historical fill shown in the diagram is the Younger Fill (see the main text for fuller descriptions). (b) The temporal record of channel and floodplain deposition and incision associated with the Older and Younger Fill model put forward by Vita-Finzi (1969).

are a classic example of Vita-Finzi's Younger Fill (Figure 11.1).

Vita-Finzi's Older and Younger Fill model is probably best remembered for reducing alluvial and related colluvial deposits in Mediterranean river systems into two timed-confined eras of valley floor aggradation (see Bintliff 2002, for an insightful recent review of VitaFinzi's contributions to Mediterranean geoarchaeology). It is clear, however, on close reading of The Mediterranean Valleys that he did in fact recognize, on the basis of the preservation of multiple alluvial terraces associated with both the Younger (Vita-Finzi 1969: 91) and Older (ibid. 92) Fills, that each comprised several erosion and sedimentation cycles.

The principal reason why Late Pleistocene and historical age alluvial units were conflated by Vita-Finzi, and by many subsequent workers, into single phases was because of the poor precision and accuracy of the dating control available at that time. Indeed this work preceded, by at least two decades, the development and application of appropriate geochronological tools (other than radiocarbon) for dating Late Quaternary alluvial 
sequences. With hindsight, attributing both aggradation episodes (particularly the Younger Fill) solely to climate change seemed, even in the late 1960s, to stretch the empirical evidence, especially as high-resolution records of Late Pleistocene and Holocene climate change were not available at the time, and most reconstructions of human activity in the Mediterranean region were also not well constrained either spatially or temporally. VitaFinzi's book was the first synthesis of Mediterranean alluvial geochronology and it set up a series of competing hypotheses of likely causative factors controlling longerterm river behaviour. This is arguably its key legacy as these bold ideas structured subsequent research and debate not only in the Mediterranean (Lewin et al. 1995; van Andel et al. 1990; Bintliff 2002) but also in the rest of Europe (Macklin et al. 2006a).

There have been many advances in the four decades since Vita-Finzi's model was first published. During the 1970s, and especially in the 1980s, a number of research programmes both in the Greek Islands (e.g. Renfrew and Wagstaff 1982) and in mainland Greece (Paepe et al. 1980; Pope and van Andel 1984; Bintliff and Snodgrass 1985), brought together interdisciplinary teams (including geomorphologists and soil scientists) coordinated by archaeologists to undertake regional Holocene landscape history projects that produced new and, in some cases, highly detailed data on human settlement in both the prehistoric and historical periods. Such information had been lacking in Vita Finzi's and other earlier studies (e.g. Judson 1963; Raphael 1973), but these later investigations were themselves similarly limited as alluvial units were still not precisely dated and regional Holocene climate records against which supposed causative factors could be tested were also still not available (Bintliff 1992; Macklin 1995).

From the mid-1980s, however, primarily as the result of the development and application of new dating techniques such as luminescence, uranium-series, and AMS radiocarbon dating, and through the reconstruction of continuous, high-resolution records of Late Pleistocene climate change (e.g. Allen et al. 1999), the chronology and controls of Pleistocene age alluvial units in the region were reassessed and in some cases radically revised (Pope and van Andel 1984; Bailey et al. 1990; Lewin et al. 1991; Fuller et al. 1998; Rose and Meng 1999; Kelly et al. 2000; Rowan et al. 2000; Woodward et al. 2001). These studies demonstrated there were multiple 'Older Fill' type Pleistocene alluvial units in most Mediterranean catchments and that Mediterranean rivers had been particularly responsive to short-term (millennial-side) climate change during the Last Glacial period. More recently, there has been a growing interest in the incidence, cause, and geomorphic impact of large flood events in the Mediterranean region and the relationship between climate change and flood frequency and magnitude.

Very large boulders $(>2 \mathrm{~m})$ on the channel bed of the Voidomatis River in the Vikos Gorge of north-west Greece are shown in Figure 11.3. It is clear that high magnitude flood flows with very high critical shear stresses are required to move such particles and direct observations of rare catastrophic flood flows in the Mediterranean (e.g. Piegay and Bravard 1997) have fostered an increased interest in their potential role in Pleistocene and Holocene sediment fluxes and valley floor development. Studies of the occurrence and impact of large floods in Mediterranean river catchments have been undertaken on Late Pleistocene (Woodward et al. 2001; Greenbaum et al. 2006), Holocene (Benito et al. 2003a) and historical (Barriendos Vallve and Martin-Vide 1998) timescales and particularly detailed reconstructions are beginning to emerge for the Late Holocene (Greenbaum et al. 2000; Benito et al. 2003b) and historical (Maas and Macklin 2002) periods. Over the last decade a number of our own doctoral research students have made important contributions in this area with field investigations conducted in the Peloponnese (Christopoulos 1998; Zorzou 2004), Crete, (Maas 1998; Noble 2004), north-west Greece (Hamlin 2000), and Corsica (Hewitt 2002).

\section{Towards a Late Quaternary Evolutionary Typology of Mediterranean River Basins}

The present-day morphology of river basins that drain to the Mediterranean Sea, as well as the nature and configuration of Late Quaternary fluvial sedimentary sequences found within them, results from the interplay between four major series of relief-forming factors (Macklin et al. 1995; Collier et al. 1995). These are crustal mobility (directed in both horizontal and vertical directions), rock type, periodic climate, and sea-level change and, in more recent times, human action (Chapter 1). The effects of short- and long-term climate change and anthropogenic activity will be discussed later in this chapter. In this section the roles of tectonics and structural controls on Late Quaternary river development are considered, together with the influence (directly and indirectly) of Pleistocene glaciation on fluvial regime, catchment sediment supply, and river sediment fluxes. Glaciation was particularly important in the mountain catchments of the northern part of the Mediterranean (Chapter 12; Hughes et al. 2006a). Taking into 


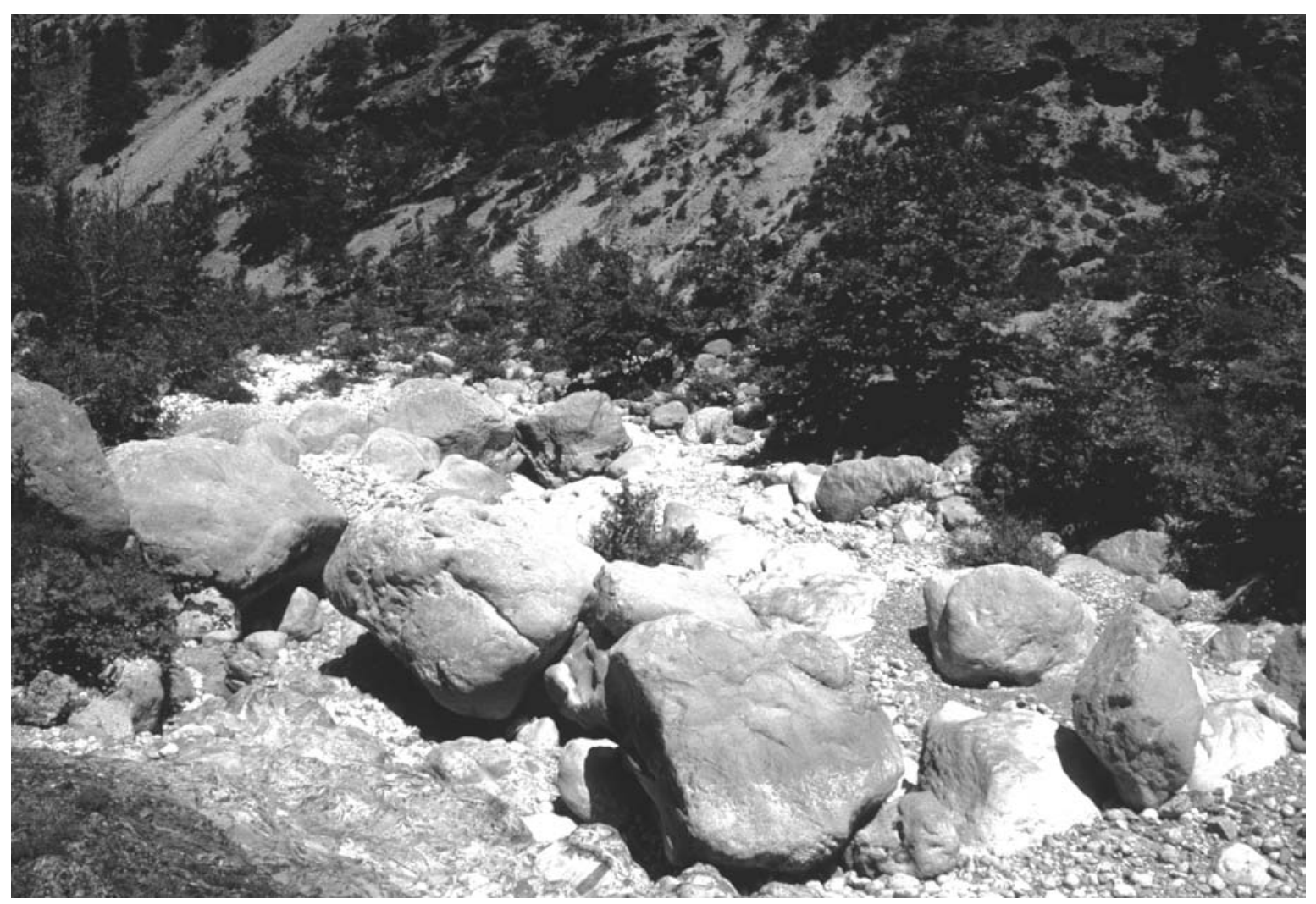

Fig. 11.3. Large boulders $(>1.5 \mathrm{~m})$ on the bed of the channel of the Voidomatis River in the Vikos Gorge of north-west Greece. Mediterranean mountain river systems commonly display good slope-channel coupling and the steep scree slopes in the background deliver coarse sediment directly to the channel system (photo: Jamie Woodward).

consideration tectonic-setting, in conjunction with the presence or absence of Late Pleistocene (or earlier) glaciation in a catchment, a simple evolutionary typology of Late Quaternary fluvial systems in the Mediterranean basin is outlined.

\section{Tectonic Setting and River Basins}

The Mediterranean basin forms the boundary zone between the Eurasian, African, and Arabian Plates (Chapter 1). The interaction of these plates has produced the Alpine fold belt that extends across the Mediterranean from Gibraltar to the Middle East. The region has an extremely complex and variable structure that comprises a number of microplates that have, in some cases, very different tectonic and resulting stratigraphic histories to the adjoining Eurasian and African cratons (Dewey et al. 1973). The result of this long-term collisional history, as far as Late Quaternary river basin development and fluvial environments are concerned, has been to produce, in general terms, three rather distinct tectonic settings around the basin for river systems that drain to the Mediterranean Sea (Macklin et al. 1995):

1. The first of these is the Precambrian African plate underlying much of North Africa. With the exception of the coastal areas of Cyrenaica in northeast Libya, this is mainly a low elevation desert environment with very infrequent seismic activity (Chapter 16). In the eastern Mediterranean, however, it is diversified by rifting in the Sinai and the Jordan Valley.

2. The second is the folded and partly metamorphosed Variscan massifs of the Iberian Peninsula, Corsica, and Sardinia in the western Mediterranean. In eastern Spain, flat-lying or gently folded Mesozoic and Cenozoic sediments cover these 
massifs. These areas are seismically quiescent and rarely affected by earthquakes (Chapter 16).

3. The third and largest landscape element in the Mediterranean is the Alpine fold-and-thrust belt that runs across the entire region from the Maghreb and Pyrenees in the west, through the Apennines, Sicily, and Alps proper in the central Mediterranean and extending eastward to Greece and Turkey (Chapter 1). From the point of view of river development, an important characteristic of all of these areas is their high relief, the active nature of tectonics throughout the Quaternary, and the availability in many catchments of terrains formed in mechanically weak, readily erodible lithologies such as flysch and marl (Woodward 1995). Tectonics and bedrock lithology have exerted a significant influence over fluvial systems in the Mediterranean basin because of their influence upon large-scale drainage basin morphology (size and shape) and river long-profiles and sediment fluxes-as shown for mainland Greece by Collier et al. (1995).

The development of Mediterranean river systems during the Pleistocene is presented below by tectonic setting (1-3). This is followed by a Mediterranean-wide discussion of the Holocene record of river basin system response to environmental change.

\section{Tectonic Setting 1: The Precambrian Plate of North Africa}

Along the presently tectonically quiescent coastline of North Africa, river systems in northern Libya that drain to the Mediterranean Sea display Late Quaternary fluvial landforms and sedimentary sequences which are generally similar over a distance approaching 1,000 km-from Tripolitania in the west (Hey 1962; Vita-Finzi 1969; Anketell et al. 1995; Gilbertson et al. 1996) to Cyrenaica in the east (Vita-Finzi 1969; Rowan et al. 2000). This suggests that, in this region, fluvial geomorphic responses to environmental change over this period have been strongly conditioned by regional geology and Pleistocene base-level change histories. Two large-scale landform elements are present in this region: a coastal plain that ranges from about 5 to $150 \mathrm{~km}$ in width, which is flanked to the south by a limestone plateau that rises steeply from the plain in a series of fault-guided escarpments (Figure 11.4a) lying up to $500 \mathrm{~m}$ above sea level. The plateau is deeply dissected by ephemeral wadi systems that emerge from the uplands onto the coastal plain as a series of coalescing alluvial fans. Due to progressive base-level fall since the Middle Pleistocene, these fans have a telescopically segmented form (sensu Blissenbach 1954) because the wadi channels have cut down into pre-existing fan sediments over several stages of development. The limestone uplands contain numerous inter-montane basins and these are commonly infilled with up to $30 \mathrm{~m}$ of Pleistocene alluvial and colluvial gravels.

Schematic block diagrams of the Late Quaternary history of a typical Tripolitanian wadi produced by VitaFinzi (1969) (Figure 11.4b) show virtually identical sedimentary architectures and terrace morphologies to those recorded by Rowan et al. (2000) in Cyrenaica more than $500 \mathrm{~km}$ to the east. A detailed study of coastal alluvial fan development in the catchment of the Wadi Zewana, in north-eastern Libya, has been carried out in conjunction with an investigation of a series of alluvial fills within the main valley. This provided the first radiometrically dated geochronology of Middle and Late Pleistocene river activity in one of the least researched areas of the Mediterranean (Rowan et al. 2000). The Wadi Zewana drains a small $\left(10 \mathrm{~km}^{2}\right)$ catchment that meets the coast to the east of Tolmeita in Cyrenaica. The headwaters of this system lie above $350 \mathrm{~m}$ on the northern slopes of the Jebal Akhdar.

Last interglacial bioclastic beach rock and overlying aeolianite (cemented dune sand) exposed in a coastal cliff eroding the toe of Zewana fan (Figure 11.4a) are found just above present sea level and indicate little or no uplift during the Late Pleistocene. Three major Late Pleistocene alluvial terraces have been mapped and radiometrically dated within the valley of the Wadi Zewana. The oldest and most extensive fill forms a prominent paired terrace approaching $25 \mathrm{~m}$ above the bed of the present river channel (Figure 11.5a). It comprises a sequence of generally flat-bedded fluvial sub-rounded gravels and sandy silts within which poorly sorted and angular colluvial gravels that thicken towards the edges of the valley are interposed (Figure 11.5b). A conspicuous feature of both fluvial and colluvial gravel units in this fill is a fine-grained matrix of terra rossa that has been eroded from the adjacent limestone slopes. This is a strongly weathered red soil found on limestone terrains across the Mediterranean (Chapter 6). Vita-Finzi (1969) noted a similarly high content of reworked terra rossa in Pleistocene wadi fills of Tripolitania. Uranium series, ESR, and OSL ages show that accelerated slope erosion, soil and regolith stripping, and valley floor infilling began sometime between $c .80$ and $70 \mathrm{ka}$ and ended before $c .42 \mathrm{ka}$ when the river trenched back down to bedrock before refilling the valley floor. To establish the broader context of this record, these ages are shown 

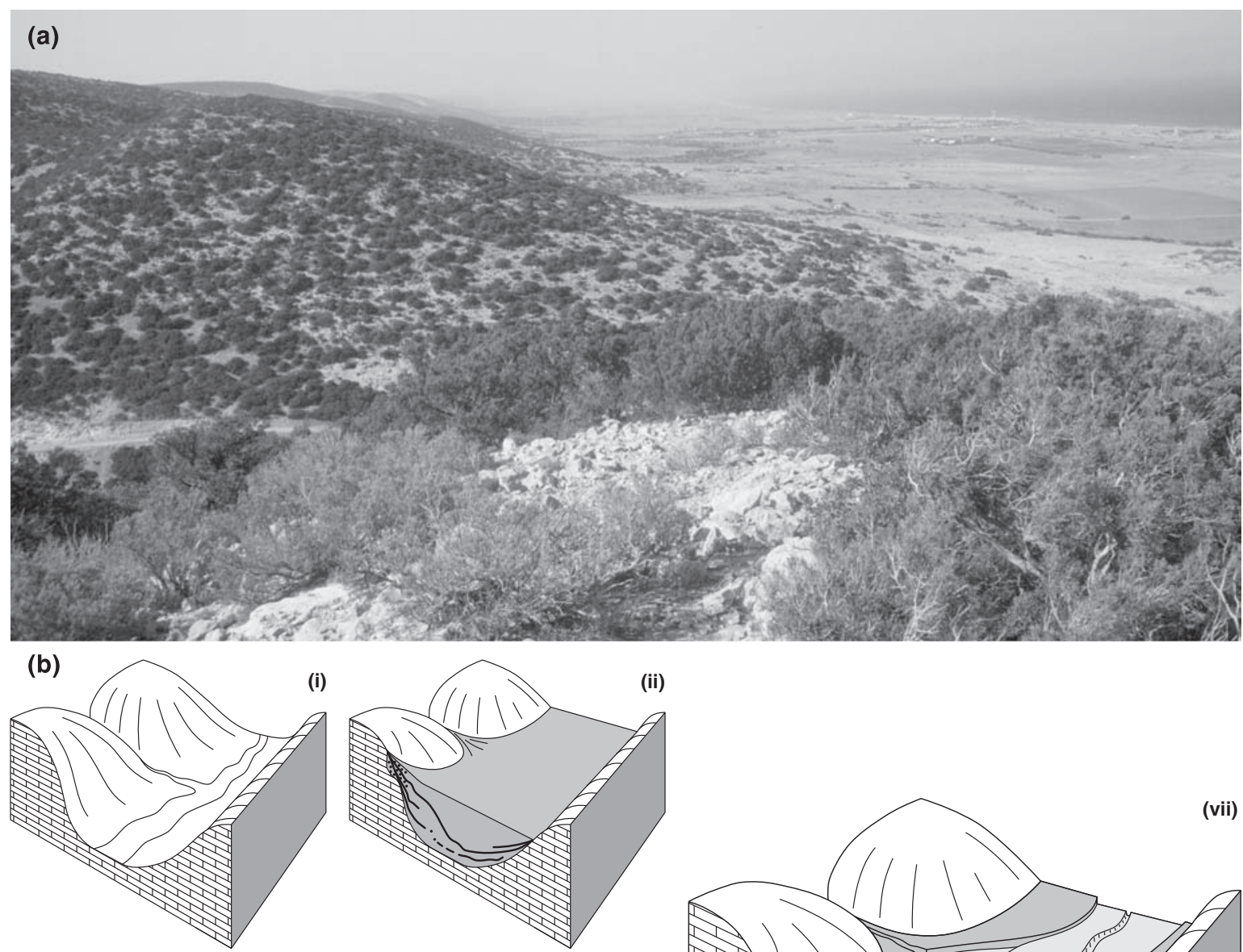

(i)
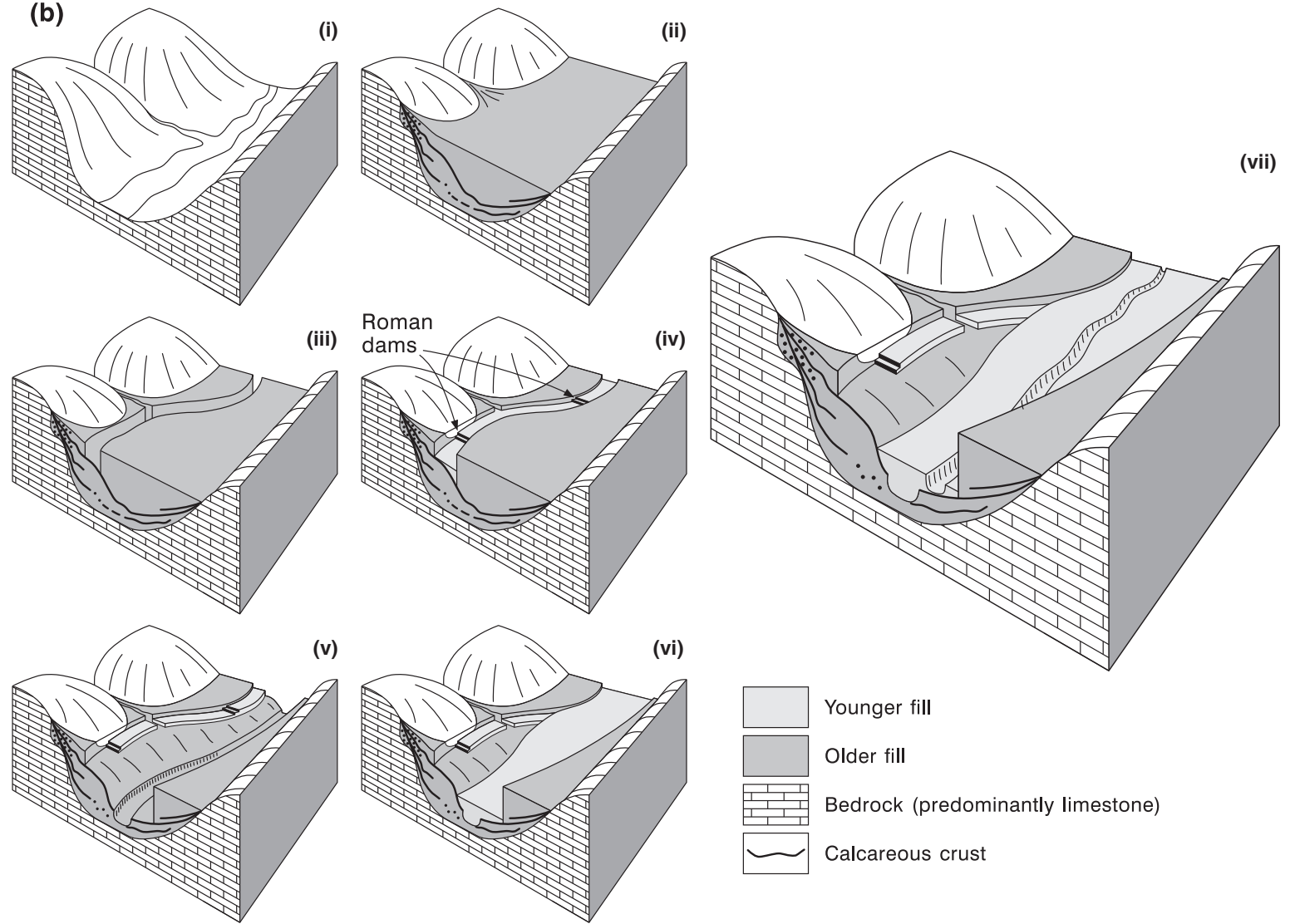

Younger fill

Older fill

Bedrock (predominantly limestone)

Calcareous crust

Fig. 11.4. (a) View looking across the coastal plain in Cyrenaica (north-east Libya) showing the lower course of the Wadi Zewana in the foreground (photo: Mark Macklin). (b) Block diagrams showing the evolution of the Late Pleistocene and Holocene alluvial stratigraphy at a trunk stream tributary confluence in wadi systems in Libya (modified from Vita-Finzi 1969). The geomorphological and hydrological characteristics of these Libyan wadis are typical of many wadi systems that drain the coastal regions around the south-eastern Mediterranean, including the northern Sinai and the southern Levant. 


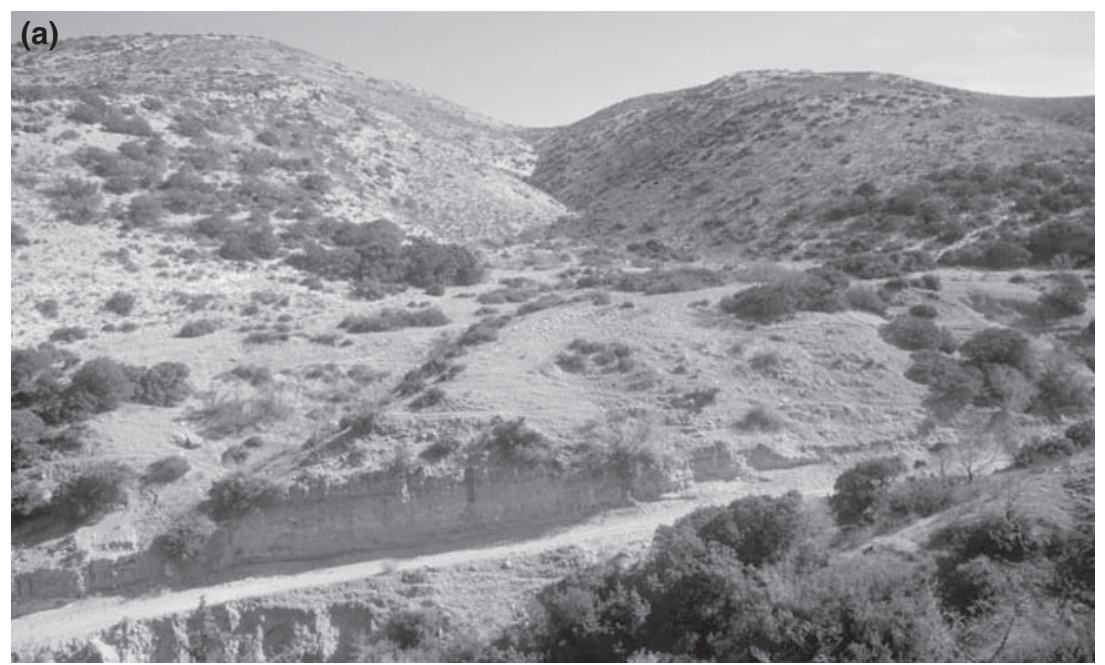

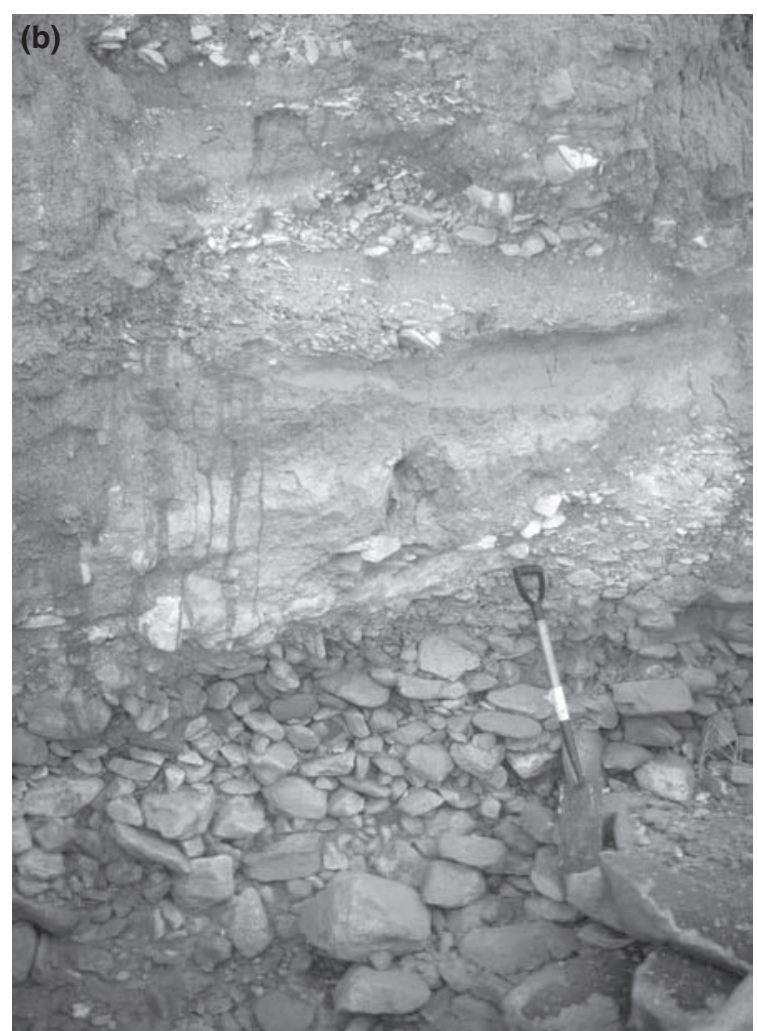

Fig. 11.5. (a) The lower course of the Wadi Zewana showing a c. $25 \mathrm{~m}$ thick exposure in Late Pleistocene alluvium. (b) A section showing the Late Pleistocene river sediments with coarse-grained angular gravels exposed at the base (photos: Mark Macklin). on Figure 11.6 along with dated alluvial units from 16 other river basins across the Mediterranean and including key study areas discussed in this chapter.

Significant slope erosion in the Zewana catchment occurred at c.23 ka and this was probably the precursor of, or perhaps coeval with, a phase of sedimentation on the coastal plain that had ended around $18 \mathrm{ka}$ (Figure 11.6). The third major alluvial terrace within the Wadi Zewana rises to $12 \mathrm{~m}$ above the present channel bed, and a date of c.12.5 ka from the middle part of the unit, and a buried Roman cross-wadi wall c.3 m below the surface of the terrace, indicates sedimentation from the end of the Late Pleistocene until incision in the post-Roman period followed by limited valley floor refilling. Although Vita-Finzi did not have radiometric dates either for the Late Glacial or for the pre-Roman Holocene in north-west Libya, as with the earlier Late Pleistocene alluvial record, there are strong parallels between the evolution of wadi systems in Tripolitania and Cyrenaica in this period.

The Wadi Zewana record suggests that Late Quaternary valley floor development in the tectonically less active parts of North Africa was characterized by an unprecedented phase of regolith and bedrock erosion that took place around $69 \mathrm{ka}$. This stripped last interglacial and earlier weathered material (terra rossa) from hillslopes to leave the bare limestone uplands of today. Although the precise duration of this phase of erosion has not yet been determined, it is clear that as the bedrock became progressively exposed in the Zewana catchment, this material was increasingly supplemented by mechanically weathered limestone gravel, resulting in aggradation along the entire trunk stream as well 


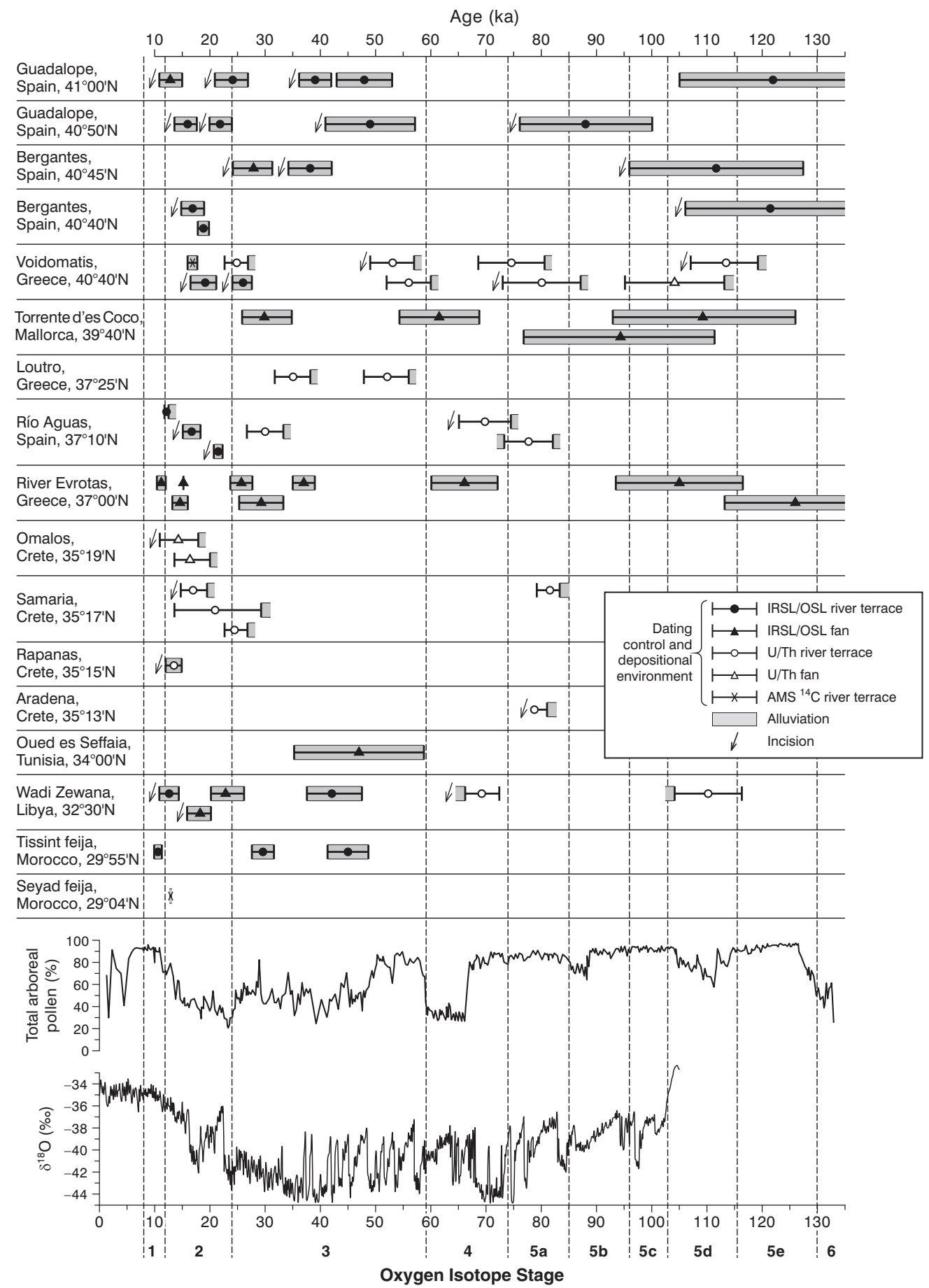

Fig. 11.6. Dated alluvial units in river systems across the Mediterranean region between c.130 and 10 ka shown in association with two proxy climate records. The river basins and reaches are ordered by latitude from north to south. The legend shows the dating methods that have been employed in each case and the error bars for each date are also shown. The dated alluvial units come from papers cited in this chapter and the proxy climate records are from Tzedakis et al. (2002). 
as in the larger tributaries (Figure 11.5). Following this major phase of aggradation, from $c .42 \mathrm{ka}$ the Wadi Zewana became progressively supply-limited with later phases of valley floor sedimentation resulting from the erosion and 'cannibalization' of the $c .69 \mathrm{ka}$ alluvial fill (see Lewin and Macklin 2003).

The period shortly after $c .69 \mathrm{ka}$ along the southern Mediterranean littoral in Libya was a time of marked geomorphic change. Indeed, it represents probably the most significant landscape transformation that has occurred in this region for the last 100,000 years and perhaps longer (Figure 11.6). This period lies close to the Marine Isotope Stage (MIS) 5/4 transition which is dated to $c .70 \mathrm{ka}$ on the SPECMAP timescale and to about 75 to $80 \mathrm{ka}$ in the GRIP ice core (Dansgaard et al. 1993 and Figure 11.6). It was marked by a sharp decline in sea-surface temperatures in the North Atlantic by as much as $5-6{ }^{\circ} \mathrm{C}$ (Bond et al. 1993) and the replacement of mixed woodland in southern Europe by open steppe (Tzedakis et al. 2002 and Chapter 4). This geomorphic 'event' set the boundary conditions for all subsequent phases of valley floor erosion and sedimentation in the region, including those that occurred during the Holocene and historical periods. It is clear that a major threshold was crossed at around $70 \mathrm{ka}$ in terms of both the rates and types of hydrological and geomorphological processes operating within the river basins of the region. Before $70 \mathrm{ka}$ geomorphic activity was relatively subdued in the catchment. After this date, however, there was a step-change increase in slope erosion and concomitant valley floor aggradation that was probably triggered by changes in vegetation type and cover - themselves related to altered precipitation regimes. Thereafter the Zewana basin became more responsive to a series of major climatic fluctuations at c. 42, 23-18, and 12.5 ka that are recorded in marine, ice core, and pollen records (Figure 11.7).

\section{Tectonic Setting II: The Hercynian Massifs and Foldbelts}

The Hercynian massifs and fold belts that form much of the central and eastern part of the Iberian Peninsula, together with the Hercynian massifs of Corsica and Sardinia that were involved in Alpine folding, comprise the second tectonic terrain with respect to a morpho-structural classification of Mediterranean river basins and their Late Quaternary development. Located away from the main plate boundaries, these areas have had relatively little seismic activity over the last 130,000 years (Chapter 16). However, gradual long-term regional uplift has created high basin relief $(34 \%$ of peninsular Spain lies between 800 and $2,000 \mathrm{~m}$ above sea level) and, with extensive outcrops of sedimentary rock susceptible to mechanical breakdown and erosion, these landscapes provide ideal conditions for the formation and preservation of river terraces (Macklin and Passmore 1995; Santisteban and Schulte 2007). Glacial moraines and Pleistocene river terraces are well preserved in the mountains of Corsica (Conchon 1986), but these records are not yet securely dated.

One of the most studied and securely dated Quaternary river terrace sequences in the Mediterranean is that of the River Guadalope and its major tributary the River Bergantes in north-east Spain that drain the Iberian Cordillera and flow northwards into the Ebro basin (Macklin and Passmore 1995; Fuller et al. 1996, 1998; López-Avilés et al. 1998). High resolution geomorphological mapping in the lower part of the Bergantes Valley has identified five major river terraces at $20-25 \mathrm{~m}$, $16 \mathrm{~m}, 10-12 \mathrm{~m}, 5-8 \mathrm{~m}$, and $2-3 \mathrm{~m}$ above present river level. Luminescence dating of alluvial fills demonstrates trunk river aggradation at c.110 ka, c.35-40 ka, c.25$7 \mathrm{ka}, \quad c .10-13 \mathrm{ka}, \quad c .7-8 \mathrm{ka}$, and $c .3 \mathrm{ka}$, respectively. In broad terms, the scale of Late Pleistocene fluvial aggradation events varies considerably-with the oldest (c.110 ka) being the largest and with each subsequent event becoming progressively smaller. It is evident that differences in both the scale and pattern of Late Pleistocene fluvial sedimentation were controlled primarily by the degree of coupling between tributaries and the axial river and the amount of sediment supplied from local slopes and tributary catchments. The period around $110 \mathrm{ka}$ saw up to $20 \mathrm{~m}$ of trunk river aggradation in the Bergantes Valley associated with exceptionally high rates of erosion and sediment delivery during the cold episode of Marine Isotope Substage 5d (Figure 11.6). This represents a 'tipping point' in catchment evolution and Late Quaternary river development in the region and appears to be directly analogous to the exceptional phase of drainage basin transformation at c.70 ka recorded in North African Mediterranean river systems discussed above. Both the $c .110 \mathrm{ka}$ and $70 \mathrm{ka}$ phases of accelerated geomorphic activity coincided with forest decline and the development of steppe-dominated landscapes as shown by pollen records in southern Europe (e.g. Allen et al. 1999; Tzedakis et al. 2002) (Figure 11.6). Similar vegetation changes are evident in later stadial events, but the magnitude of the geomorphic response in north-east Spain during Marine Isotope Substage 5d suggests that climatic forcing of catchment erosion, sediment yields, and fluvial system dynamics were amplified in comparison to later cold 


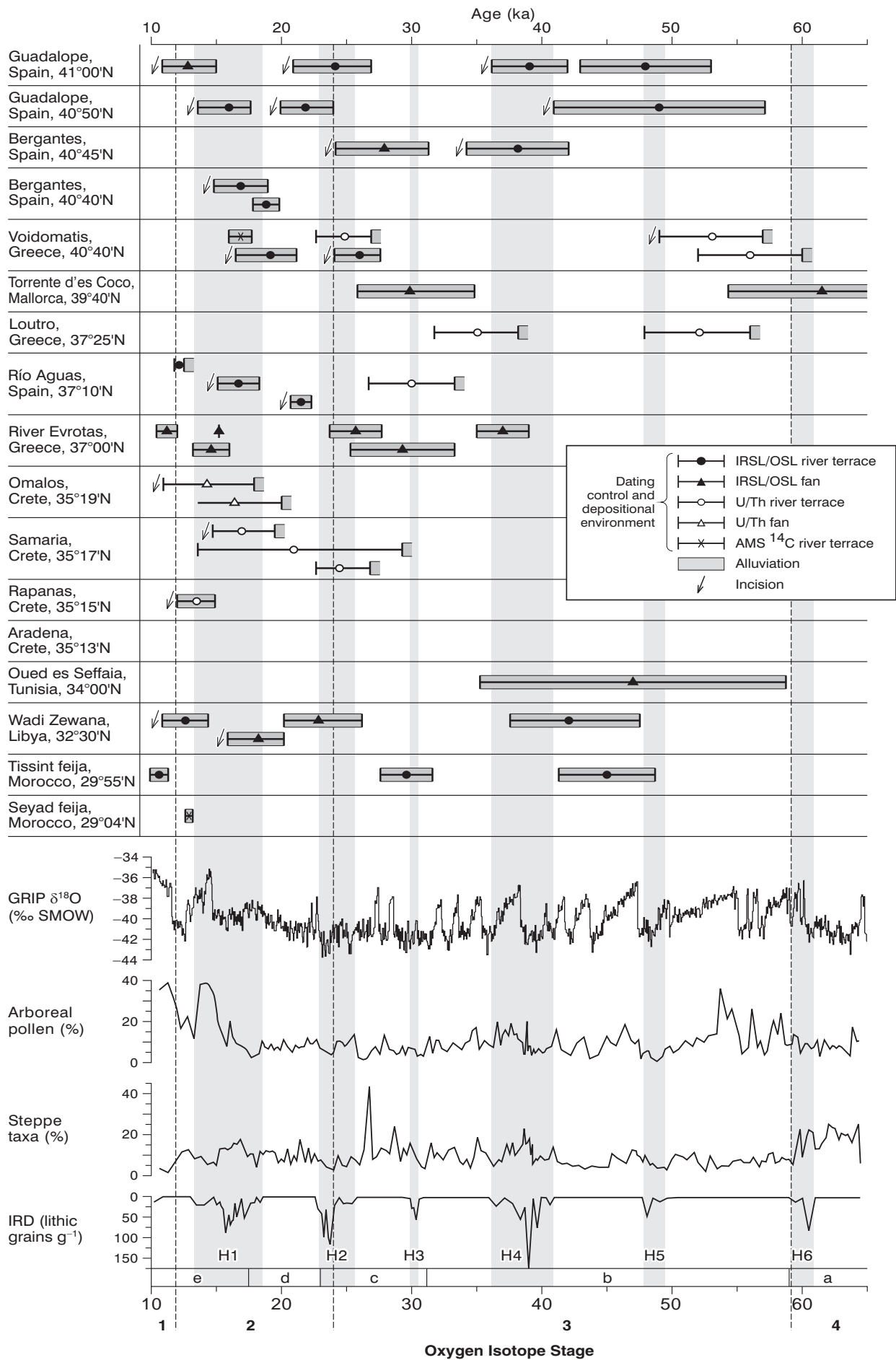

Fig. 11.7. Dated alluvial units in river systems across the Mediterranean region between c.65 and $10 \mathrm{ka}$. The shaded columns show Heinrich Events 1-6 (see Chapter 4). The river basins and reaches are ordered by latitude from north to south. The legend shows the dating methods that have been employed in each case and the error bars for each date are also shown. The dated alluvial units come from papers cited in this chapter and the proxy climate records are from Roucoux et al. (2005). The five palynological sections (a to e) from Roucoux et al. (2005) are also shown. 
periods, perhaps through a combination of exceptional rates of runoff and sediment supply.

Subsequent phases of valley floor refilling in northeast Spain are coeval with Heinrich event 4 (c.36-41 ka) and the Younger Dryas Stadial (Figure 11.7). Heinrich event 4 is believed to have been one of the most extreme climatic events of MIS 3, judged by the major flux of icerafted detritus in the North Atlantic from the Laurentide ice sheet (McManus et al. 1998) and the reduction in the thermohaline circulation (Tzedakis et al. 2002). In comparison to substage $5 \mathrm{~d}$, however, there was limited sediment supply from tributary streams during these periods and material that was delivered from tributary catchments was generally fine-grained in calibre.

As elsewhere in the Mediterranean, while phases of large-scale Late Pleistocene river aggradation in the Bergantes Valley are correlated with Heinrich events and with stades of the Dansgaard-Oeschger cycles (Macklin et al. 2002), the record of river response to sub-orbital-scale climate change is more complex and spatially variable. In the tectonically quiescent Mediterranean regions of North Africa and the Iberian Peninsula, environmental changes were characterized primarily by reorganizations within the fluvial sediment system - the most notable of which were major fluctuations in tributary stream sediment delivery, and changes in alluvial storage within high-order valleys. These adjustments occurred in both areas over extended periods. In the drainage basins in north-east Spain, these began during the transition to the last cold stage (MIS $5 \mathrm{~d}$ to $5 \mathrm{a})$ and in north-east Libya were initiated during the MIS 5/4 transition (Figure 11.6). Over timescales of $10^{4}$ years and longer, sediment yields have therefore been highly variable and data from the River Bergantes demonstrate very clearly that some of the larger $\left(>1200 \mathrm{~km}^{2}\right.$ ) Mediterranean river systems have been highly sensitive to changes in climate.

\section{Tectonic Setting III: The Alpine Mountain Belt}

The largest and most geologically complex tectonic terrain in the Mediterranean is that resulting from Alpine orogenesis. It comprises the mountain chains of the Pyrenees, the Alps, the Balkans, and Turkey related to continental collision, and fold-and-thrust belts in south-east Spain, the Maghreb, and the Italian Peninsula related to back arc opening (Chapter 1). These landscapes include the most seismically active areas of the Mediterranean (Chapter 16). In many mountain regions within this tectonic province, particularly along the northern Mediterranean littoral of Italy, the former Yugoslavia, Greece, and Turkey, climatic cooling during the Pleistocene provided favourable conditions for glacier development (Chapter 12). Glaciers had a significant impact on sediment supply and catchment hydrology, and these effects have been observed in the Pleistocene fluvial record in river valleys draining glaciated drainage basins in north-west Greece (Lewin et al. 1991; Woodward et al. 1992, 1995 2008), northwest Slovenia (Bavec et al. 2004) and north-east Spain (Sancho et al. 2003). It is therefore logical for the purposes of developing an evolutionary typology to subdivide Mediterranean river basins within the area affected by Alpine orogenesis into those catchments which supported important Pleistocene cirque and valley glaciers and those that did not. The Pleistocene glacial history of the Mediterranean mountains has recently been reviewed by Hughes et al. (2006a) and is examined in detail in Chapter 12.

\section{Glaciated River Basins in the Alpine Fold Belt}

The widespread occurrence of glacial landforms and sediments in the headwaters of many Mediterranean river basins has been known for well over a century (Cvijić 1900; Niculescu 1915; Almagià 1918; Chapter 12). However, outside north-east Spain (Pyrenees; Sancho et al. 2003), north-west Slovenia (South Julian Alps; Bavec et al. 2004) and, most notably, the Voidomatis River basin in the Pindus Mountains of northwest Greece (Bailey et al. 1990; Lewin et al. 1991; Woodward et al. 1992, 1995 2001; Macklin et al. 1997, 2002; Hamlin 2000; Hamlin et al. 2000; Woodward et al. 2008), the downstream impact of this glacial activity upon Pleistocene river development is still relatively poorly known.

A substantial body of geomorphological, sedimentological, and geochronological data has been assembled for the Middle and Late Pleistocene history of the Voidomatis River basin $\left(384 \mathrm{~km}^{2}\right)$. A large area of the basin's headwaters lies in the high karst of the Pindus Mountains (Mount Tymphi, 2,470 m) and was subject to the build-up and decay of cirque and valley glaciers on at least three occasions over the last 500,000 years or so (Woodward et al. 2004; Hughes et al. 2006b). The glacial sequence on Mount Tymphi is now one of the best-dated in Europe and is discussed more fully in Chapter 12. In brief, the record comprises extensive Middle Pleistocene glacial sediments and landforms that have been dated to MIS 12 (between $c .478$ and $423 \mathrm{ka}$ ) and MIS 6 (between c.190 and $126 \mathrm{ka}$ ) using uraniumseries methods. In contrast, only small cirque and valley glaciers and rock glaciers developed during the last 

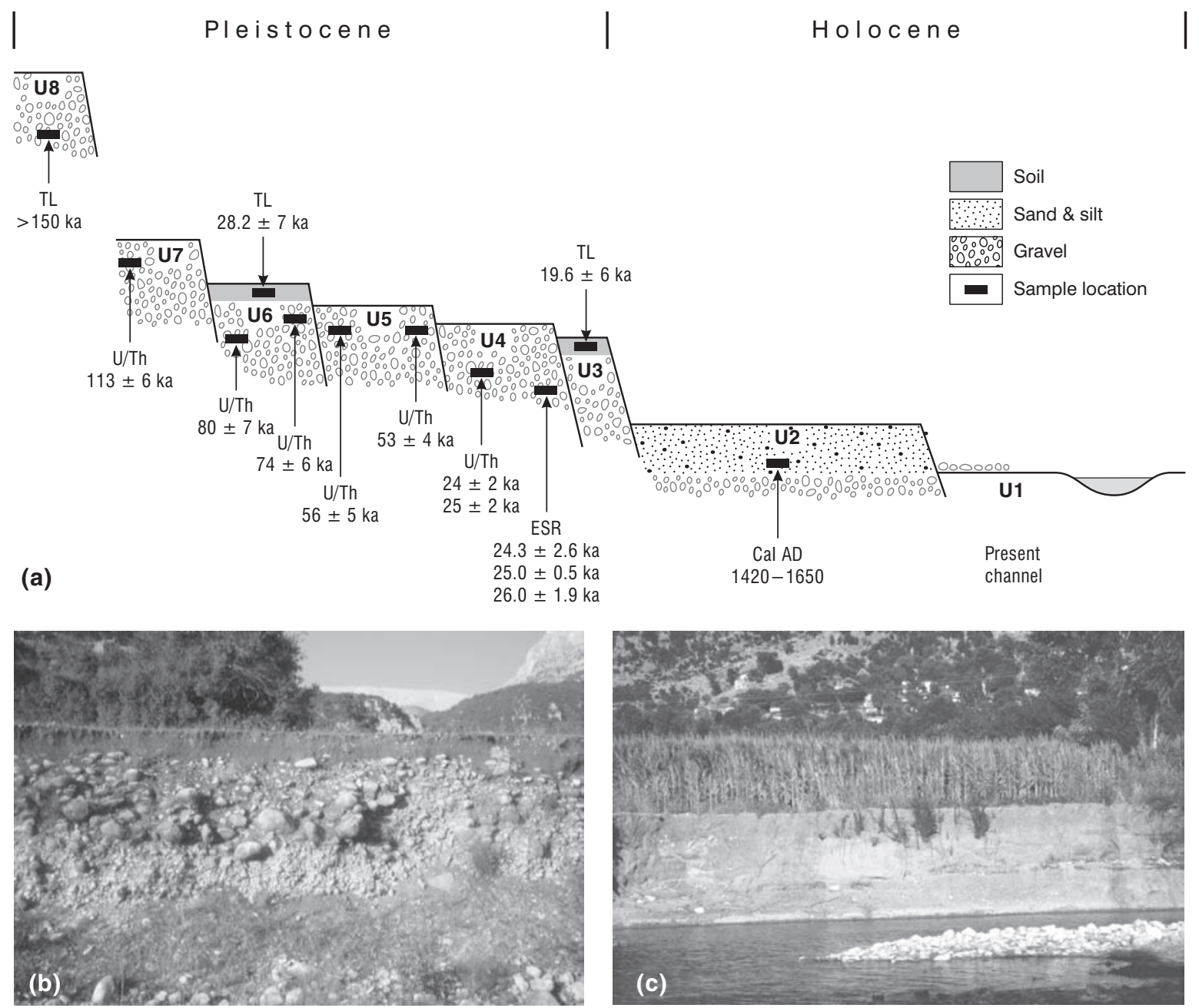

Fig. 11.8. (a) The Pleistocene and Holocene fluvial stratigraphy in the middle and lower reaches of the Voidomatis River basin showing eight alluvial units including the modern channel complex. Based on a figure in Hamlin et al. (2000) using data from Lewin et al. 1991; Macklin et al. 1997; Hamlin et al. 2000). Key to dating methods: U/Th = uranium thorium, ESR = electron spin resonance, TL = thermoluminescence (both dates on the U6 and U3 soils are TL dates. U2 has been dated using radiocarbon). The photographs show (b) Unit 6 in the Lower Vikos Gorge at the location of soil profile A of Woodward et al. (1994) and (c) Unit 2 in the southern part of the Konitsa basin a few hundred metres downstream of Boila rockshelter (photos: Jamie Woodward).

cold stage or MIS $5 \mathrm{~d}$ to 2 (between $c .111$ and $11.5 \mathrm{ka}$ ) (Hughes et al. 2006b).

Late Pleistocene river sediments are well preserved in the lower reaches of the Voidomatis River and a detailed record of river aggradation and dissection, and its relation to headwater glaciation, has been reconstructed (Lewin et al. 1991; Macklin et al. 1997; Woodward et al. 2001, 2008). The fluvial record in the lower reaches of the Voidomatis River is shown schematically in Figure 11.8a along with the array of dates that constrain the phases of fluvial sedimentation. Uniquely, the geochronology combines these four methods and sample types: uranium-series dating of calcite cements, thermoluminescence dating of fine-grained alluvial soils, electron spin resonance dating of fossil teeth, and AMS radiocarbon dating of charcoal. Alluvial units (U7 to U4) have a very similar lithological composition (Figure 11.8b) - they are dominated by coarse limestone gravels $(>94 \%)$ and they contain a fine-grained matrix derived from the 
glacial deposits in the catchment headwaters (Woodward et al. 1992; Hamlin et al. 2000). These four units represent the Aristi Unit sediments originally described by Lewin et al. (1991) that have been related to glacial activity in the catchment headwaters (Figure 11.8b). The Aristi Unit was later subdivided into four phases of aggradation and incision following detailed mapping of the lower reaches of the basin in the late 1990s and, crucially, through the application of uraniumseries dating to carbonate cements in the coarse gravel matrix (Hamlin et al. 2000) (Figure 11.8a). These ages are also plotted on Figures 11.6 and 11.7 along with other radiometrically dated alluvial units from across the Mediterranean. These phases of aggradation represent periods of enhanced sediment supply to the lower reaches from a range of sediment sources including: direct input from headwater glaciers, fluvial reworking of pre-existing glacial and alluvial sediments, and cold climate weathering of hillslopes. It is interesting to note that the Voidomatis River terrace sequence provides a more detailed archive of Late Pleistocene environmental change than does the glacial record in the catchment headwaters (Chapter 12).

Unit U8 is the Kipi Unit of Lewin et al. (1991) and it has a very different lithological composition to the later, limestone-rich units. It is dominated by flysch and ophiolite gravels (Figure 11.8b) and has a flysch-rich matrix. It must therefore predate the first phase of glaciation in the catchment (MIS 12) and the TL date of $>150 \mathrm{ka}$ (Figure 11.8a) is a minimum age. U3 is the youngest Pleistocene alluvial unit and is equivalent to the Vikos Unit of Lewin et al. (1991). The lithology of this unit shows that it was deposited after the final period of Late Pleistocene glacial activity on Mount Tymphi and it overlaps with a phase of Late Glacial slackwater sedimentation recorded in the deposits of Boila rockshelter in the lower reaches of the Voidomatis River (Woodward et al. 2001) and shown in Figure 11.9. The postglacial record of river behaviour is dominated by progressive incision that is interrupted in the late Holocene by the development of a distinctive low terrace (U2) formed in fine-grained overbank sediments (Figure 11.8c).

\section{Non-glaciated River Basins in the Alpine Fold Belt}

The Sorbas basin, part of the Betic Cordillera of southeast Spain, lies within a rapidly uplifting area, with Pliocene to recent average uplift rates of $c .80 \mathrm{~m} \mathrm{Ma}^{-1}$ (Mather 2000; Chapter 1). This basin was not glaciated during the Pleistocene and provides one of the bestdocumented examples of the effects of tectonics on Late Pleistocene and earlier drainage network development in the Mediterranean (Harvey and Wells 1987).

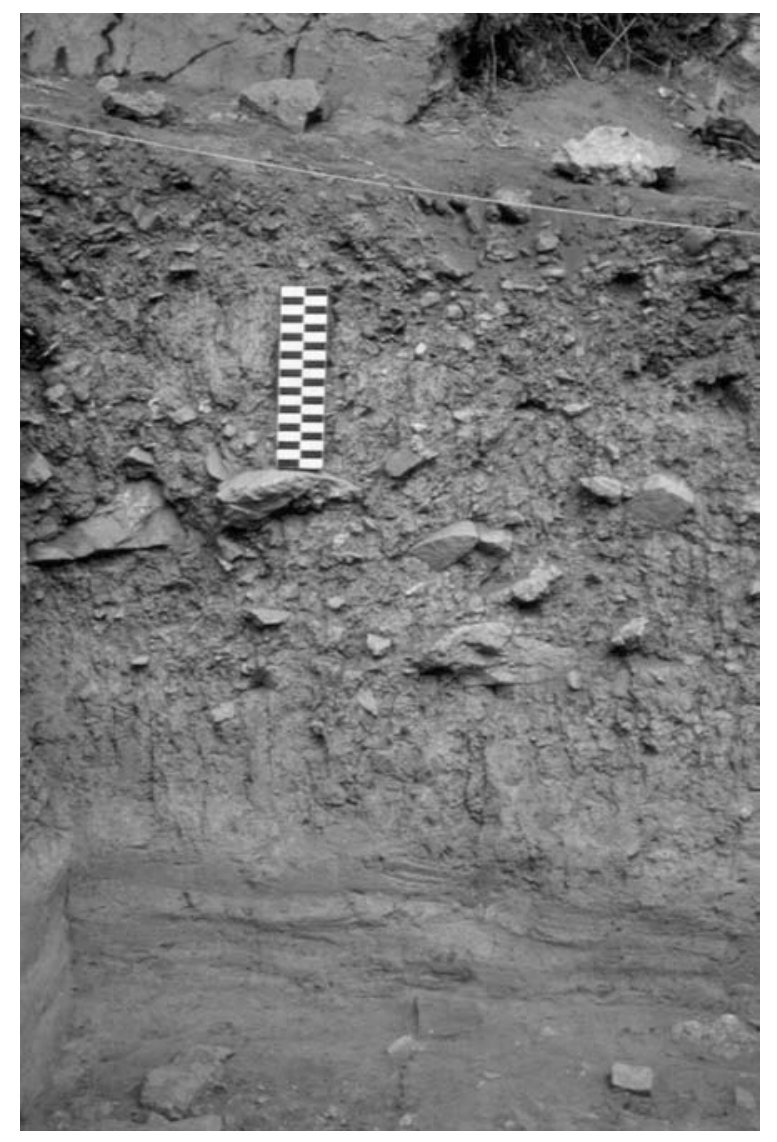

Fig. 11.9. The sediments exposed during the excavations at Boila rockshelter in the lower reaches of the Voidomatis River in northwest Greece (after Woodward et al. 2001). The bottom of the section shows the fine-grained slackwater sediments produced by large floods prior to the Late Upper Palaeolithic use of the site. The sediments above contain angular limestone clasts derived from the walls and ceiling of the rockshelter. The scale is in $\mathrm{cm}$ (photo: Jamie Woodward).

Accelerated headward erosion of the Río Aguas, stimulated by regional differential uplift, resulted in progressive reorganization of the drainage network by river capture. The most dramatic modification of the network was a major capture of the south-flowing proto Aguas/Feos by the east-flowing lower Aguas, an aggressive subsequent stream that was developing by headward erosion along the outcrop of a weak marl unit. Three pre-capture river terraces can be traced following the proto-drainage across the Sorbas basin and through the southern mountain ranges (Harvey and Wells 1987). Uranium series dating of pedogenic calcretes developed on the surface of these river terraces 


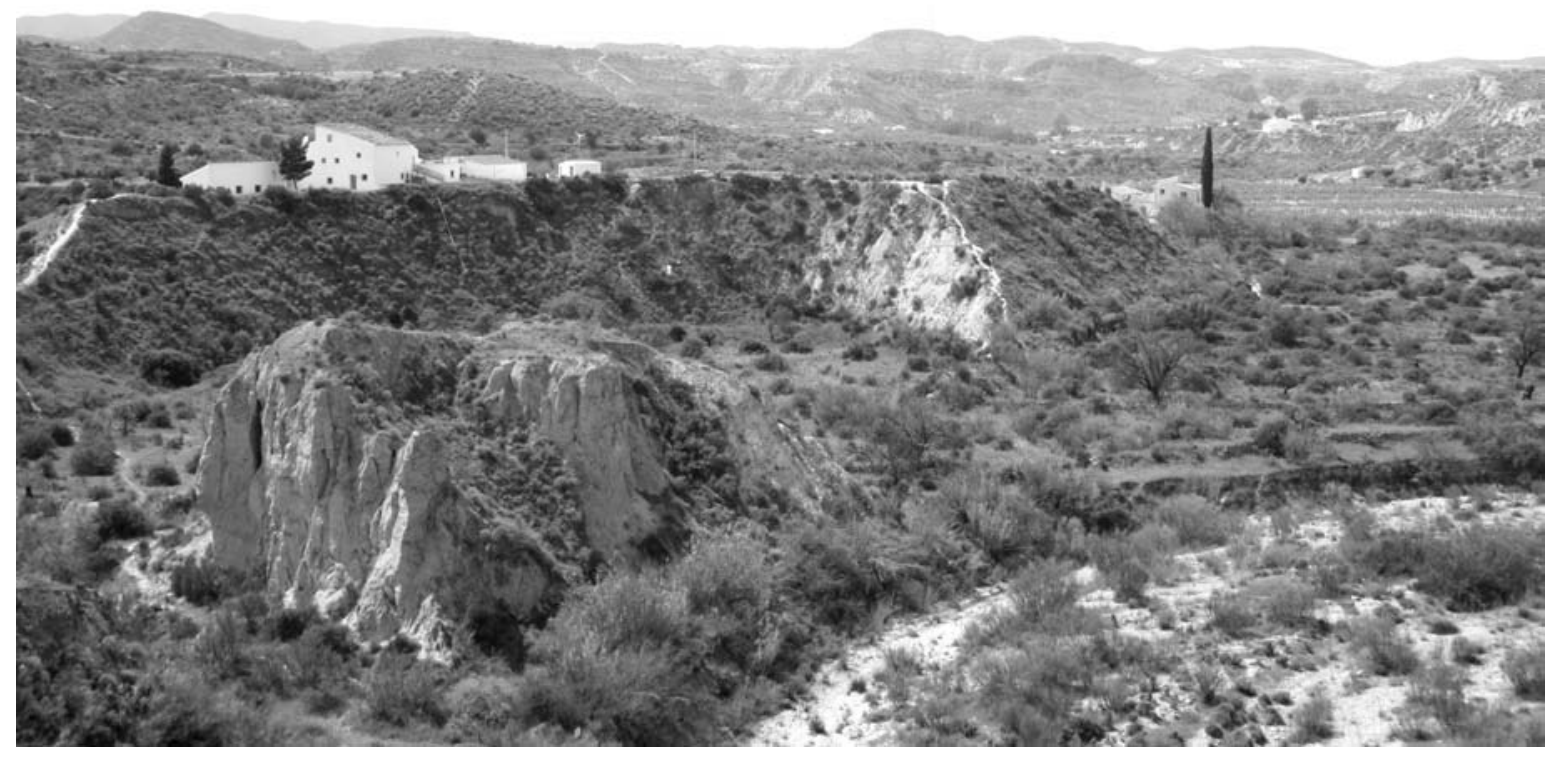

Fig. 11.10. The deeply incised valley floor and Quaternary terraces of the Río Aguas in south-east Spain (see Chapter 1). This reach is a few kilometres downstream of Sorbas and shows the Urra field centre on the high terrace (photo: Jamie Woodward).

has recently been undertaken (Candy et al. 2005). These workers argue that the terraces date to $c .304 \mathrm{ka}, 207 \mathrm{ka}$, and $70 \mathrm{ka}$, respectively, with capture of the Río Feos by the lower Aguas taking place some time between 69.8 and $67.9 \mathrm{ka}$. These dates, along with three further OSL dates published by Schulte et al. (2007) are also plotted on Figure 11.6. The dates for the two oldest terraces indicate that river incision of $10-15 \mathrm{~m}$ began towards the end of the interglacials of MIS 7 and 9, followed by limited refilling $(c .5 \mathrm{~m})$ of the valley floor. In the case of the $c .70$ ka river terrace, calcite-cemented root mats in the middle part of the gravel-dominated unit show that it comprises two aggradational phases; one dated to sometime before $77 \mathrm{ka}$ and the second shortly after $77 \mathrm{ka}$ (Candy et al. 2005) (Figure 11.6).

Post-capture terraces ( $<70 \mathrm{ka})$ are clearly expressed in the Sorbas basin (Figure 11.10), but patterns of river incision and aggradation, as well as badland development and landslide activity, have been governed by their location relative to the river capture site (Harvey et al. 1995). Upstream of the capture, a 90-m drop in base level included headward incision that over the last $70 \mathrm{ka}$ has migrated $20 \mathrm{~km}$ upstream. Largescale drainage network incision in the upper reaches of the Aguas following the $c .70 \mathrm{ka}$ capture event has resulted in the development of steep and unstable slopes. These slopes have been especially prone to badland erosion (particularly in weaker lithologies) and largescale rotational landslides (Griffiths et al. 2002) that have resulted in local damming, ponding, and finegrained sedimentation in the Aguas system (Mather et al. 1991; Kelly et al. 2000; Chapter 1). Downstream of the capture site, along the lower Aguas, rates of incision during the Late Pleistocene have not been as high but there has been increasing valley widening through lateral river migration (Harvey et al. 1995) (Figure 11.10).

The wider significance of Harvey and his colleagues' work in the Sorbas basin for understanding river development in the tectonically active parts of the Mediterranean affected by Alpine orogenesis lies in its identification of the differential roles that climate, tectonics, lithological variability, and river capture have had in regional landscape development. Two different styles of Pleistocene river evolution can be recognized-each reflecting differing relationships between these factors (Harvey et al. 1995). The first style exhibits progressive incision, punctuated by episodic 
aggradation and dissection in response to long-term uplift of the basin, and river terraces are weakly divergent in headwater areas becoming parallel to one other further down the system. The second dissection style reflects major base-level change, the local impact of which is governed and intensified by river capture. River terraces diverge to the point of capture and then converge downstream. Analysis of soil development on both pre- and post-capture fluvial units does not identify any time-progressive behaviour of individual terraces (Harvey et al. 1995). This is an important observation as it implies that switches between fluvial dissection and aggradation took place relatively rapidly and that these occurred throughout the system-almost irrespective of local tectonic context-in response to climatically controlled changes in sediment supply. In this case, the primary role of tectonics has been to control the context within which short-term river aggradation and incision processes have operated during the Late Quaternary.

In those parts of the Mediterranean that have seen active volcanism during the Late Quaternary (Chapter 15), basalt flows have interacted with long-term river activity in a very distinctive way. For example, part of the Gediz River basin in western Turkey lies within the Kula Quaternary volcanic field and basalt flows have filled gorge reaches to depths of many tens of metres on several occasions during the Middle and Late Pleistocene. These events created major perturbations to the river's long profile and forced the trunk stream to re-incise the valley floor (Westaway et al. 2003). In some reaches these basalt flows cap Quaternary fluvial sediments and, because the basalts can be dated using $\mathrm{K}-\mathrm{Ar}$ and $\mathrm{Ar}-\mathrm{Ar}$ methods, they can be utilized to generate age models for rates of regional uplift and long-term river behaviour. Westaway et al. (2003) have obtained a series of dates from basalt-capped river terraces to develop a model of Pliocene to Quaternary surface uplift for western Turkey.

Using a range of methods, including geophysical survey, Branca and Ferrara (2001) have examined the interactions between drainage system development and volcanic activity on the slopes of Mount Etna in Sicily during the course of the Middle and Late Pleistocene. Between 170 and $100 \mathrm{ka}$, the main channel of the Alcantara River was periodically invaded by lava flows from peripheral activity of the central volcano. A major modification of the regional drainage network began around 45-40 $\mathrm{ka}$ as the main eruptive centre of the volcano (the Ellittico volcano) increased in size. Over the next 25-30 ka, the gradual expansion of this volcano led to a progressive northward diversion of the Alcantara channel and to the capture of an adjacent river catchment (Branca and Ferrara 2001).

\section{River Systems and Holocene Environmental Change}

The most contentious area of environmental change and river system research in the Mediterranean has centered on the interpretation of the Holocene record. VitaFinzi (1969) identified a single phase of alluviation in the Holocene that took place between the end of the Roman Period and c.400 BP as shown in Figure 11.2b. In the river basins that he observed, his Younger Fill consisted primarily of fine-grained sediments commonly underlain by basal gravels. He argued that this period of fluvial deposition was a result of increased erosion and flooding produced by a cooler and wetter climate across the Mediterranean during the Medieval Period (Figure 11.2b). Vita-Finzi's (1969) interpretation of the Holocene alluvial record in the Mediterranean initiated a major debate that continues today.

With hindsight, several weaknesses in Vita-Finzi's thesis for Holocene river development can be identified. The dating control for the Younger Fill was based on a very small number of radiocarbon samples and it therefore proved impossible to precisely determine the onset of fluvial aggradation and subsequent incision in the way that he envisaged across the entire region. Indeed, many subsequent studies have shown much more complex Holocene records that include major phases of fluvial sedimentation and incision that took place much earlier than the single phase of post-classical alluviation represented by the Younger Fill. For example, Figure 11.11 shows a series of river terraces in the Torcicoda River valley of central Sicily where a major phase of fluvial sedimentation began in the Neolithic period before c. $5.5 \mathrm{ka}$.

In very general terms, it can be argued that VitaFinzi's (1969) proposed mechanism of river response to Holocene climate change-involving large-scale shifts in atmospheric circulation across the Mediterraneanhas been shown to be broadly correct by later studies. However, in the late 1960 s there were no independent, high-resolution climate records to test his proposal for the timing and mechanism of Holocene river alluviation and erosion and this was still the case when VitaFinzi (1976) explored the potential significance of the latitudinal pattern of river basins and a diachronous response to Late Holocene climate change. Again, the very limited dating control for the fluvial records did not allow these novel ideas to be properly tested. 


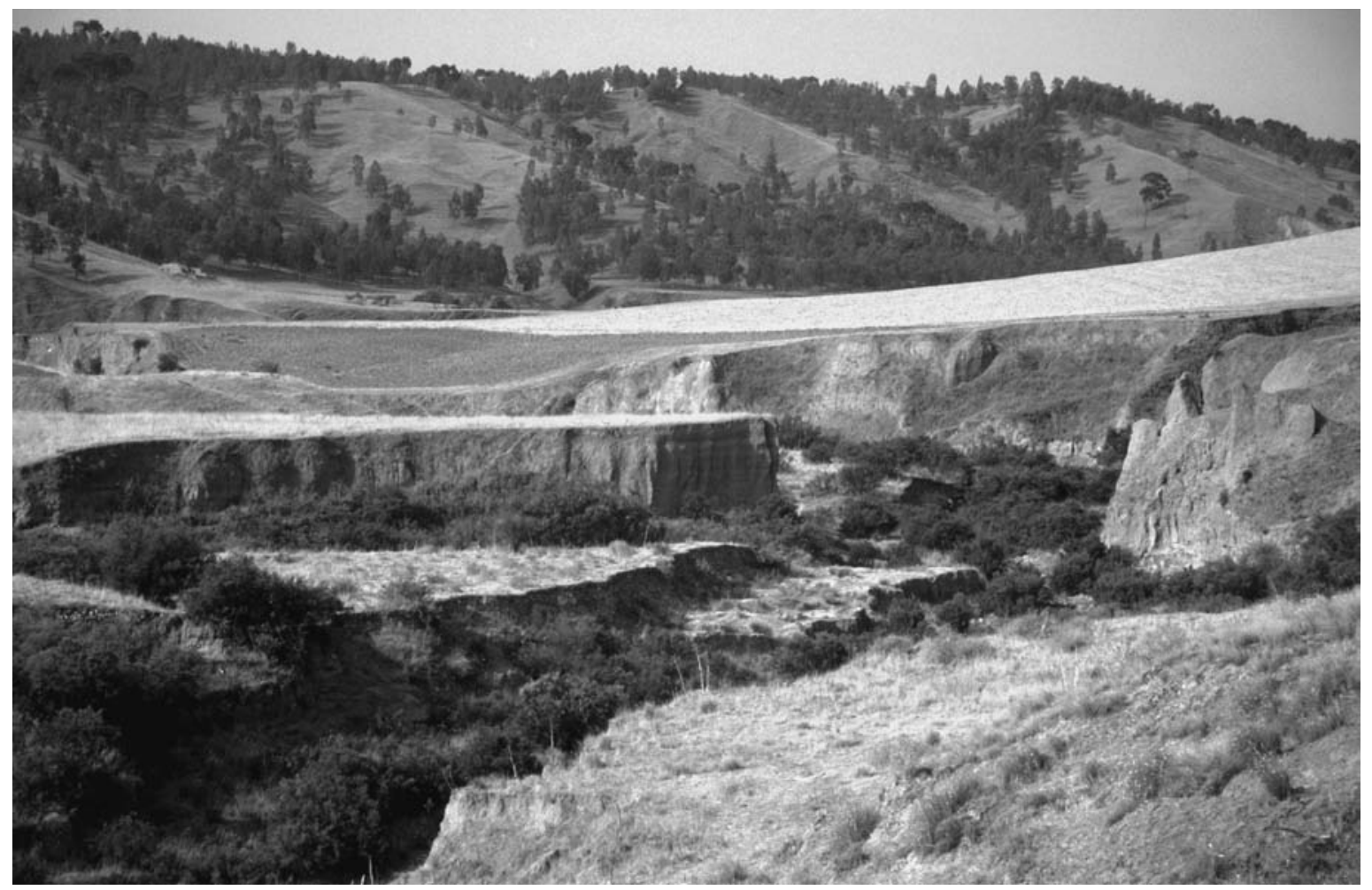

Fig. 11.11. The Holocene alluvial sediments and terraces in the middle reaches of the Torcicoda River in central Sicily (photo: Jamie Woodward).

Finally, Vita-Finzi's (1969) model did not incorporate the potential impacts of human activity in river basins during the course of the Holocene and this omission attracted widespread criticism. Other workers have argued that forest clearance and a range of farming practices-including ploughing and hillslope terracing — had very significant impacts upon river basin hydrology and the transfer of sediment from hillslopes to river channels (Chapters 6, 8, and 9). Brückner (1986) provides a good summary of the view that emerged in the two decades following the publication of The Mediterranean Valleys. He provides a long list of human impacts on the Mediterranean landscape that took place during the course of the Holocene including the expansion of settlements, the destruction of the protective vegetation cover, the cultivation of grain and olive trees, widespread goat-keeping, and overpopulation. Brückner (ibid. 16) argued that these human impacts 'all contributed to the areal denudation and erosion which caused the filling up of the valley bottoms and the growth of deltas. This clearly demonstrates man's predominant part in the evolution of the physical environment in historical times. Compared to that, the influence of climate and tectonics were subordinate.'

In a review of The Mediterranean Valleys, Karl Butzer argued that the Older and Younger Fill model was an oversimplification and that alluviation episodes were not 'universally contemporary' across the region. He also argued that 'the field evidence is seldom adequate to support the bold generalizations and hypotheses put forward' (Butzer 1969: 53). Over a decade later, in a review of dating and correlation issues surrounding Holocene alluvial sequences in various parts of the Old World, Butzer (1980: 138) argued that, in Mediterranean river basins, 'the dominant pattern is one of accelerated soil erosion in response to human misuse of the landbeginning locally during the late Bronze Age and becoming more universal after the economic decline of the Roman Empire'. In contrast to many publications that appeared around this time, Butzer (1980) also acknowledged the important role of climate in driving river basin processes-but he still argued a strong case for 

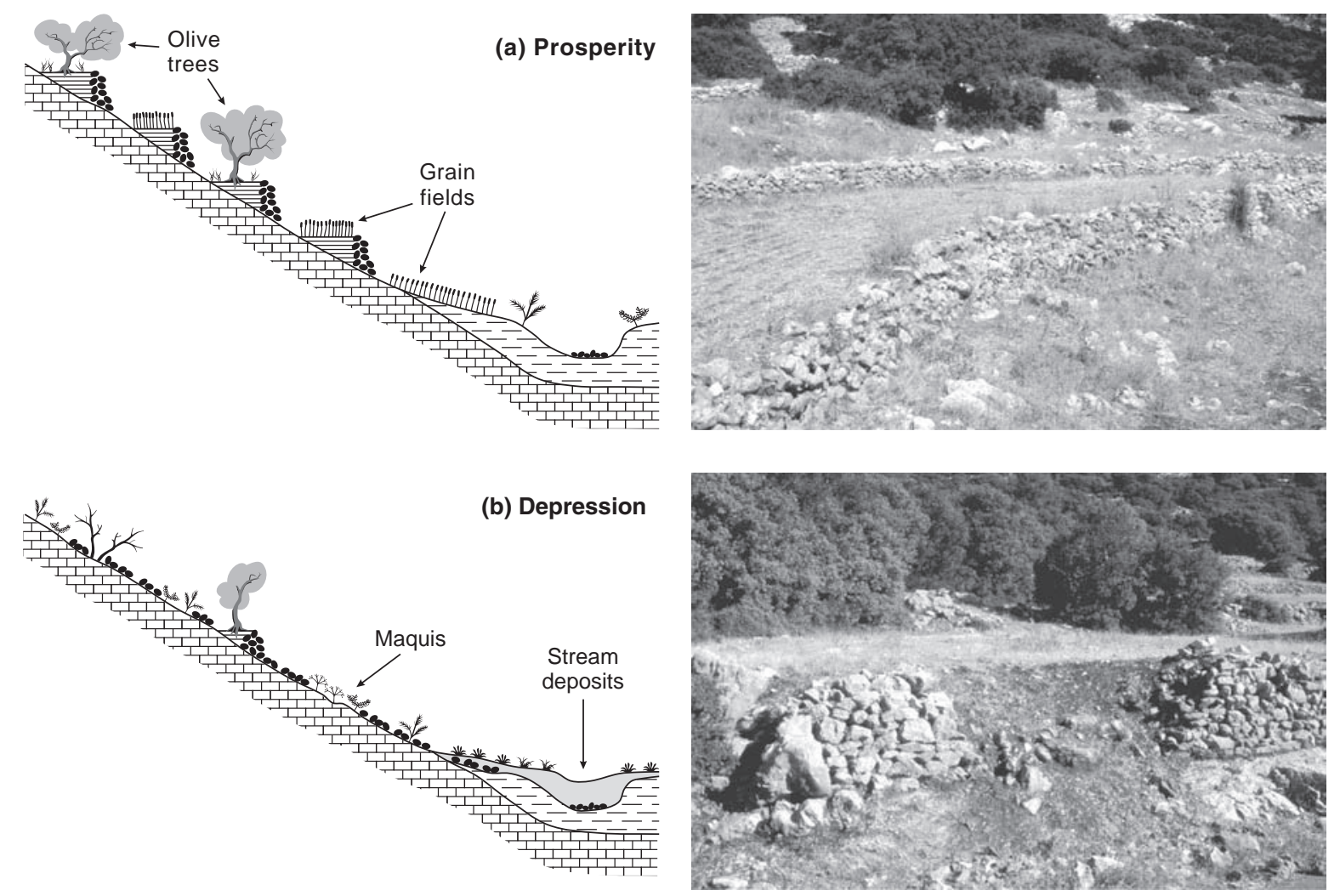

Fig. 11.12. The prosperity and depression model of slope stability and soil erosion modified from van Andel and Runnels (1987). See text for discussion. The photographs show (top) well-maintained stonewalled agricultural terraces and (bottom) a breached terrace wall with sediment movement downslope (photos: Jamie Woodward; both from the Ladonas catchment in the western Peleponnese, Greece).

the role of human action: 'Climatic impulses may have favoured such geomorphic activation, but the variable timing, and the unprecedented extent and scope of these slope and valley changes within the Holocene record, remain inconceivable without a pre-eminently cultural impetus.'

During the 1970s and 1980s, several large-scale archaeological surveys were conducted in the Mediterranean and this period saw the emergence of modern landscape archaeology in the region and new perspectives on landscape change. Building on Butzer's arguments, work in Greece by Tjeerd van Andel and others on the Argolid Peninsula of the eastern Peloponnese led to the development of a model of hillslope and valley floor dynamics driven by economic factors (van Andel et al. 1986; van Andel and Runnels 1987). This model proposed that socio-economic and demographic factors were the primary controls on hillslope processes and river alluviation and erosion. Figure 11.12 illustrates their model of alternating prosperity and depression and their respective impacts on hillslopes and river channels. In short, this work argued that agricultural terraces were well maintained during periods of economic prosperity; with only limited sediment transfer from hillslopes to river channels. Phases of channel alluviation were associated with periods of economic decline when terrace walls became degraded and this promoted the transfer of runoff and sediment to valley bottoms (Figure 11.12). 'In the absence of independent evidence for increased precipitation and runoff and for other, circumstantial reasons, we have attributed those [streamflood deposits] to neglect of a well-established system of terraces and gully check dams, with the inevitable vertical erosion, soil removal, and increased flooding of streams that such neglect entails' (van Andel et al. 1986: 125).

Despite the relatively poor dating control for many Holocene fluvial records, van Andel et al. (1990) 


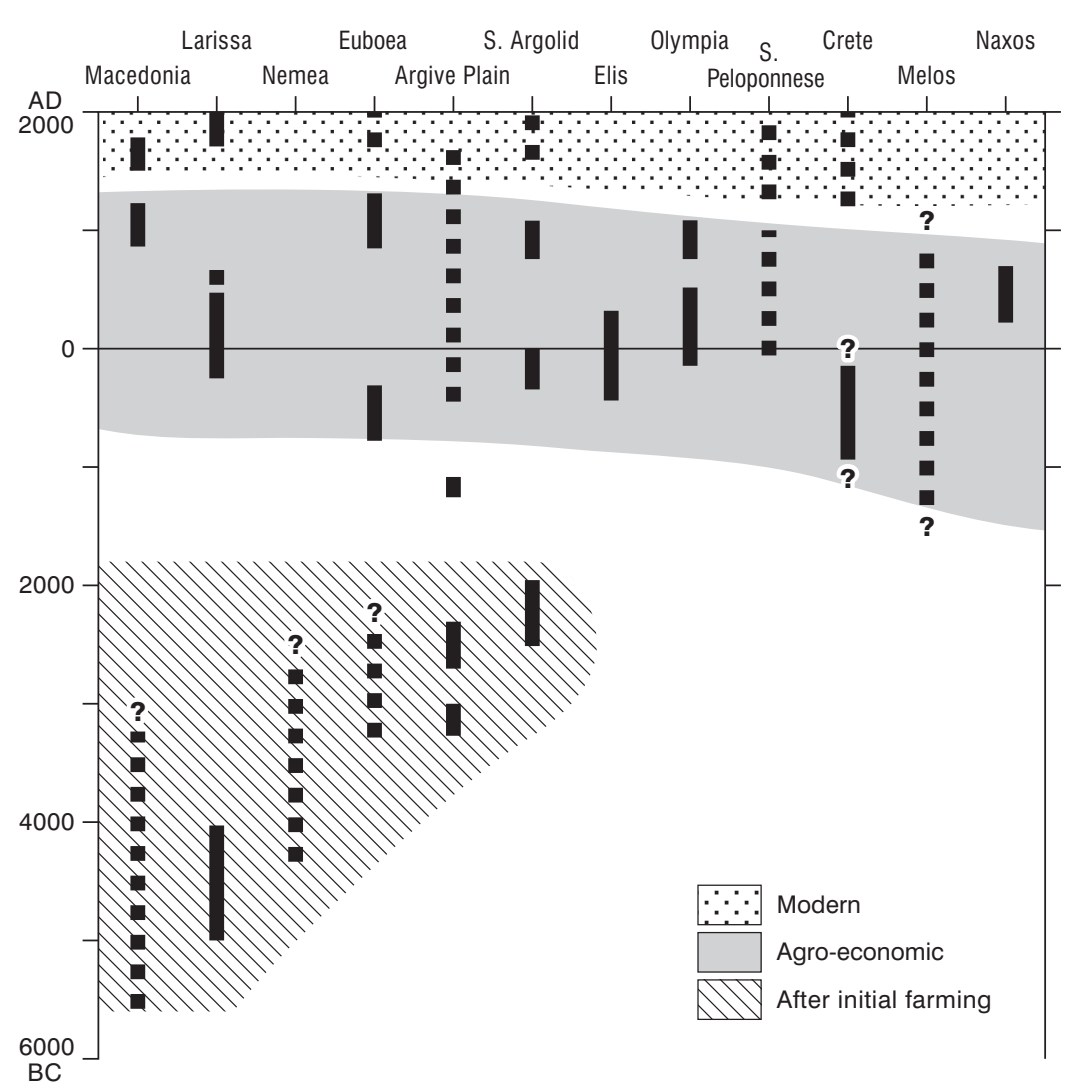

Fig. 11.13. Patterns of Holocene alluviation in Greece for the last 8,000 years modified from van Andel et al. (1990). compared the data from several river basins across Greece (Figure 11.13) and argued that the observed pattern of river aggradation reflected the variable timing and impact of catchment disturbance that followed the introduction of different agricultural technologies. This analysis showed clearly that there were multiple phases of Holocene alluviation in Greece, but a rigorous evaluation of the causative factors was still not possible given the lack of independent and high-resolution proxy climate records.

A large volume of research has been conducted in the lower reaches of Mediterranean river basins to examine the mechanisms, timing, and underlying controls behind coastal progradation in the postglacial period (Kraft et al. 1975). Marine embayments were transformed into floodplains during the Holocene; and reconstructions of coastal palaeogeography have proved crucial for the interpretation of archaeological sites such as ancient Troy and Ephesus (Kraft et al. 1980, 2007). Ancient Troy was located on an embayment close to the sea-whereas today it lies $6 \mathrm{~km}$ from the Aegean coast (Kraft et al. 1980). The interactions between river deltas, coastal plains, and sea-level change in the Holocene are discussed more fully in Chapter 13.

More recent research in the Mediterranean has focused on the significance of large flood events in shaping the Holocene fluvial record and has incorporated very detailed work on alluvial sequences within high resolution dating frameworks based on large numbers of radiocarbon dates. Benito (2003) has compiled a Holocene record of river aggradation and incision along with flooding episodes for parts of both the African and European Mediterranean (Figure 11.14). Region-wide river aggradation can be recognized in the Medieval Period, the Iron and Bronze Ages, the Neolithic, and Late Mesolithic. A high incidence of major floods is associated with both valley floor sedimentation and incisionand indicates the potential variability of river response to hydrological change in different geomorphological settings. Although this was an important review, the lack of dating precision for key areas still largely precluded 


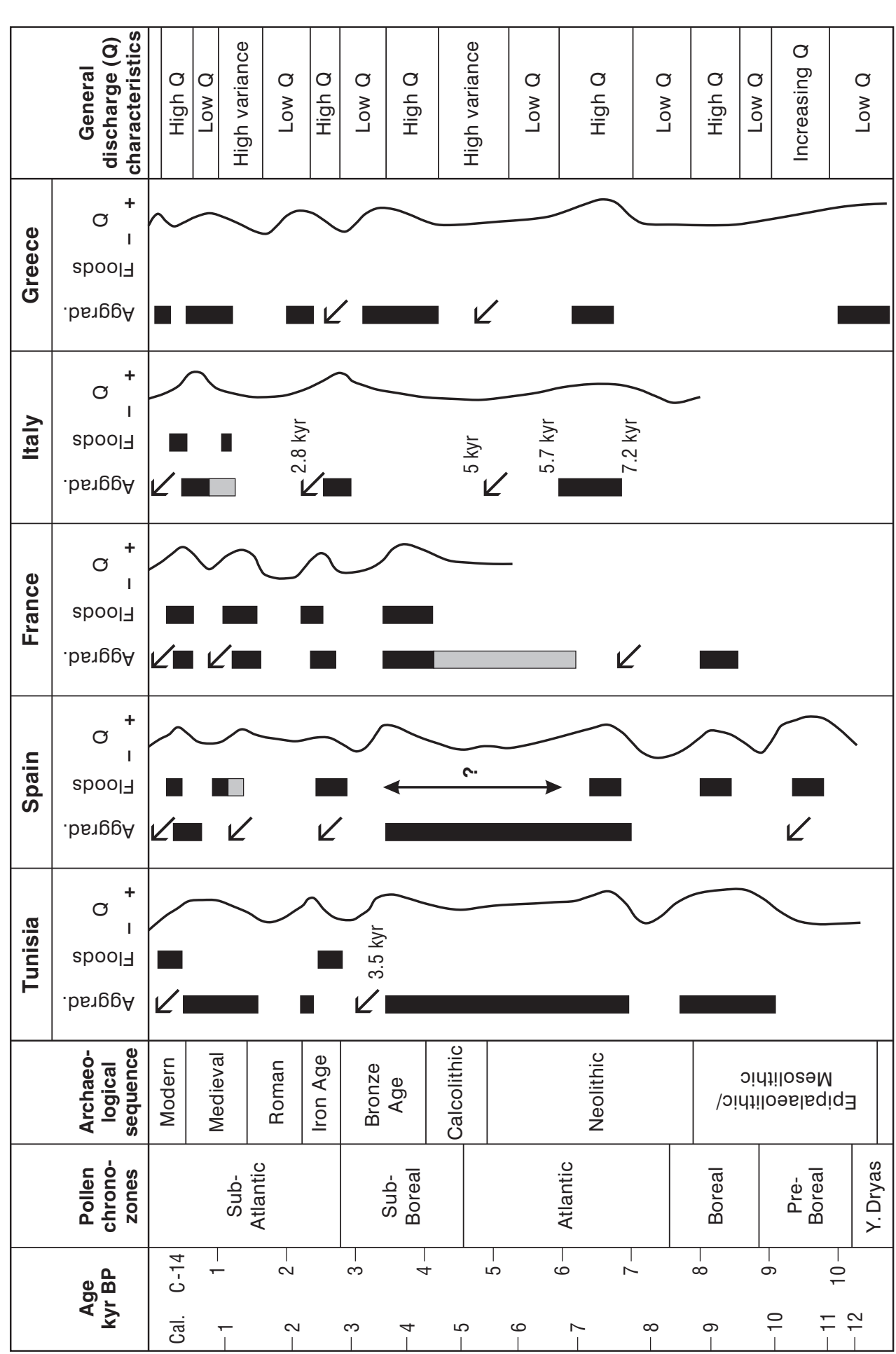


secure process-based correlations with periods of rapid climate change and human impact.

Following ${ }^{14} \mathrm{C}$-based fluvial database development and meta-analysis techniques pioneered by Macklin and Lewin in the UK (Macklin and Lewin 2003; Macklin et al. 2005), this methodology is now beginning to be applied to Mediterranean river basins. For example, Thorndycroft and Benito (2006) have compiled and analysed radiocarbon-dated Holocene fluvial units in Spain with a particular emphasis on slackwater flood deposits (but also including dates from overbank fine sediments and coarse gravel facies) formed over the last 3,000 years (Figure 11.15a, b). Their recent analysis shows that fluvial activity in Spain over the last 11,000 years or so (Figure 11.15a) has been markedly periodic, but with the majority of fluvial units dated to the last 1000 years (Figure 11.15b).

This probability-based assessment of the sedimentary flood record has allowed for more meaningful and robust correlations with documented historical floods (Figure $11.15 \mathrm{c}$ ) and with high-resolution climate records from the North Atlantic (Figure 11.15d). Using this approach, Spanish Holocene flood deposits can be compared for the first time to those elsewhere in Europe and with lake level records and climate proxies from the North Atlantic (Figure 11.16). This comparison shows that six of the major flood episodes in Spain (identified with an asterisk on the far right of Figure 11.16)-particularly over the last 5,000 years-coincide with flooding in the northern part of Europe, and with periods of cooler climate and high lake level. These periods of cooler climate affect river basin processes throughout Europe, including the northern part of the Mediterranean basin (Macklin et al. 2006a).

Much of the work that followed in Vita-Finzi's footsteps in the 1970s and 1980s was hindered by three major problems. First, despite the rhetoric, there were, in effect, only very limited improvements in dating control for the fluvial record and, in most cases, this prevented effective testing of the competing theories. Second, the long-term record of land use change remained poorly documented and rather poorly dated in most regions. The age of stone-wall terracing, for example-which represents a key modification of the hillslope sediment system across many parts of the Mediterranean-is very difficult to establish (Moody and Grove 1990; van Andel et al. 1990). Third, detailed proxy records of Holocene climate change have only recently become available for the Mediterranean region and it can be argued that a truly convincing Mediterranean-wide assault on the nature and controls of river response to Holocene envi- ronmental change has not yet taken place. Wider application of the radiocarbon database approach across the Mediterranean region will allow the Holocene fluvial record to be evaluated against the high-resolution climate records and the existing archaeological and historical records of human activity in river catchments in a much more rigorous manner.

\section{Mediterranean River Systems and 'The Little Ice Age'}

Climatic conditions in the Mediterranean region during the 'Little Ice Age' (LIA, c.AD 1450-1850) were generally cooler and wetter than present (Grove 1988; Grove and Conterio 1995; Grove 2001). There is a growing body of data to suggest that this was a very significant period of fluvial activity across the region with enhanced sediment supply from hillslopes to river channels and a greater frequency of large floods (Barriendos Vallve and Martin-Vide 1998). There is also evidence for glacier expansion in the headwaters of some Mediterranean river basins during this period (Hughes et al. 2006a; Chapter 12).

A number of studies have successfully applied lichenometry to date coarse-grained flood sediments in steep-gradient mountain catchments. This has allowed the development of high-resolution flood histories for the last few centuries. This approach has provided new insights into river behaviour during the LIA as instrumental hydrological records are commonly too brief or absent. One such study has focused on the Aradena Gorge in south-west Crete. This steep fluvial system drains the southern slopes of the Lefka Ori Mountains and Maas and Macklin (2002) have used geomorphological evidence to compile a record of recent flood events in the gorge using lichenometry to date the coarse flood deposits. They have identified twelve periods within the last 150 years when floods were more frequent than the last 10 years or so of the twentieth century. (Figure 11.17a). The periods of enhanced flooding appear to coincide with negative or declining phases of the North Atlantic Oscillation (Chapter 3). Using boulder size as a proxy for flood magnitude, Figure $11.17 \mathrm{~b}$ shows the seventy-five flood units plotted against estimated age. This analysis shows that the largest floods in this record took place in the middle of the nineteenth century towards the end of the LIA. The full record from the Aradena Gorge shows a decrease in flood magnitude in the second half of the nineteenth century, an increase in the size of floods up to about 1930, and then a progressive decline in the second half of the twentieth century. It is important to appreciate 
(a)

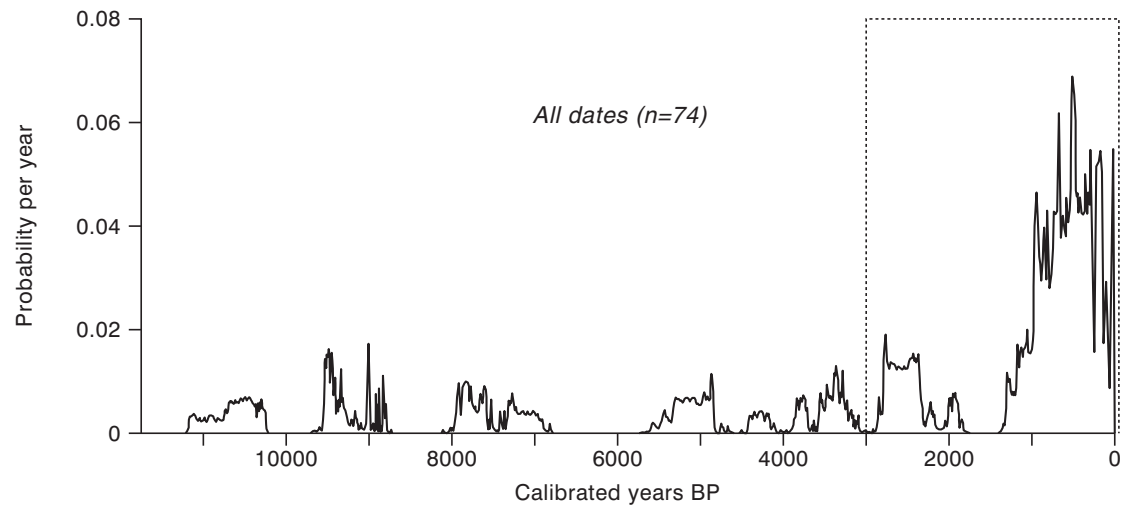

(b)

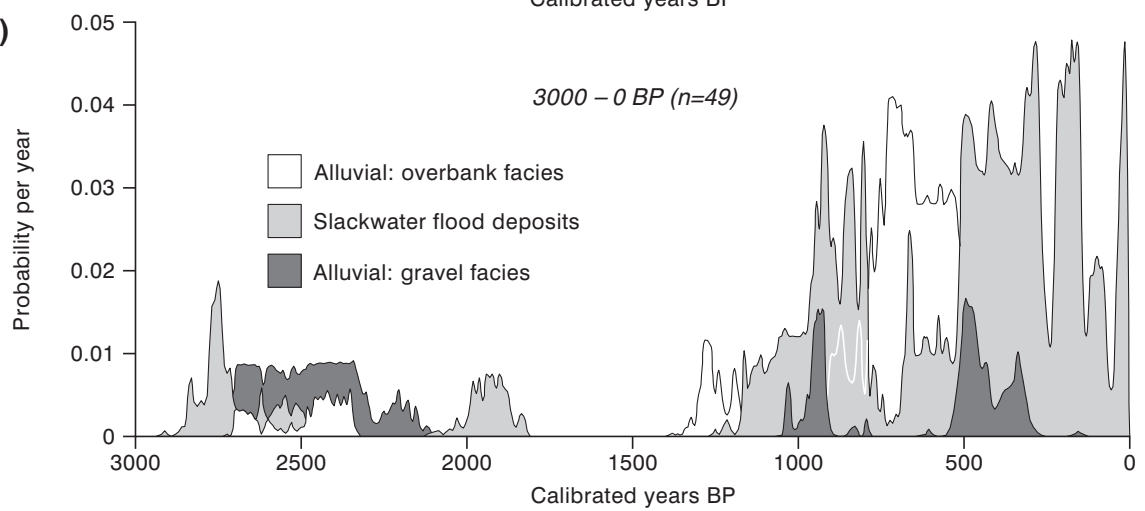

(c)

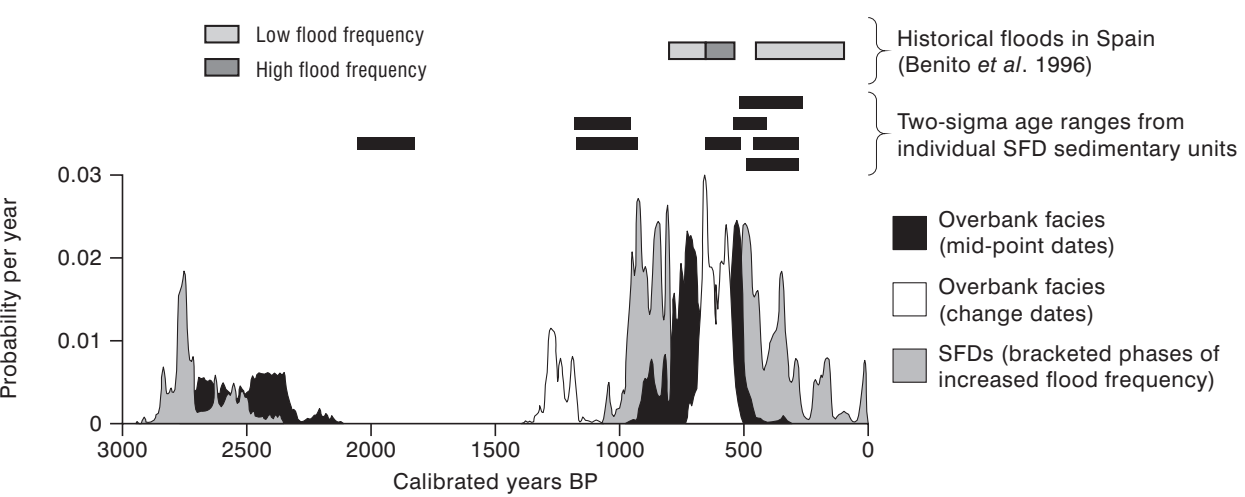

(d)

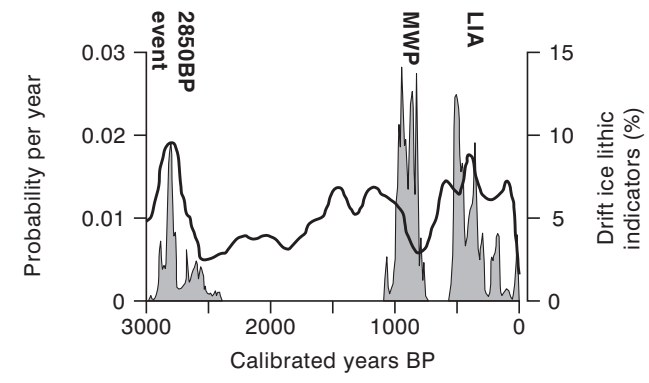

Fig. 11.15. (a) A summed probability plot for radiocarbon dates from Holocene alluvial records in Spain (11 ka to present). (b) The boxed area in (a) showing probability plots for each of the three alluvial depositional contexts shown. (c) Summed probability plots based on the change and mid-point alluvial data sets and the bracketed slackwater flood deposits. (d) A summed probability plot for the radiocarbon dates from the slackwater sediments shown in relation to the North Atlantic drift ice index. LIA = Little Ice Age and MWP = Medieval Warm Period. (All figures modified from Thorndycraft and Benito 2006). 


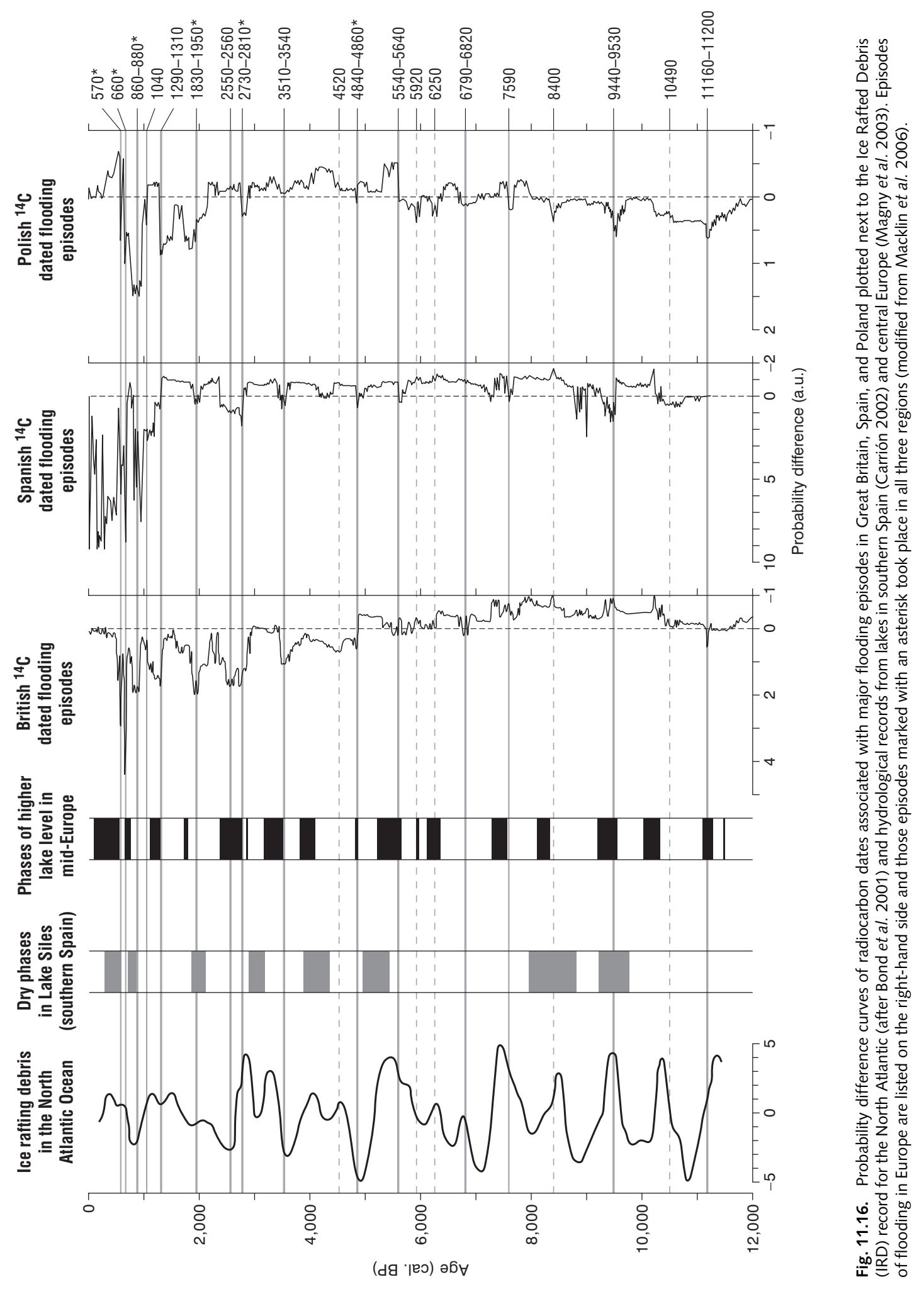


(a)
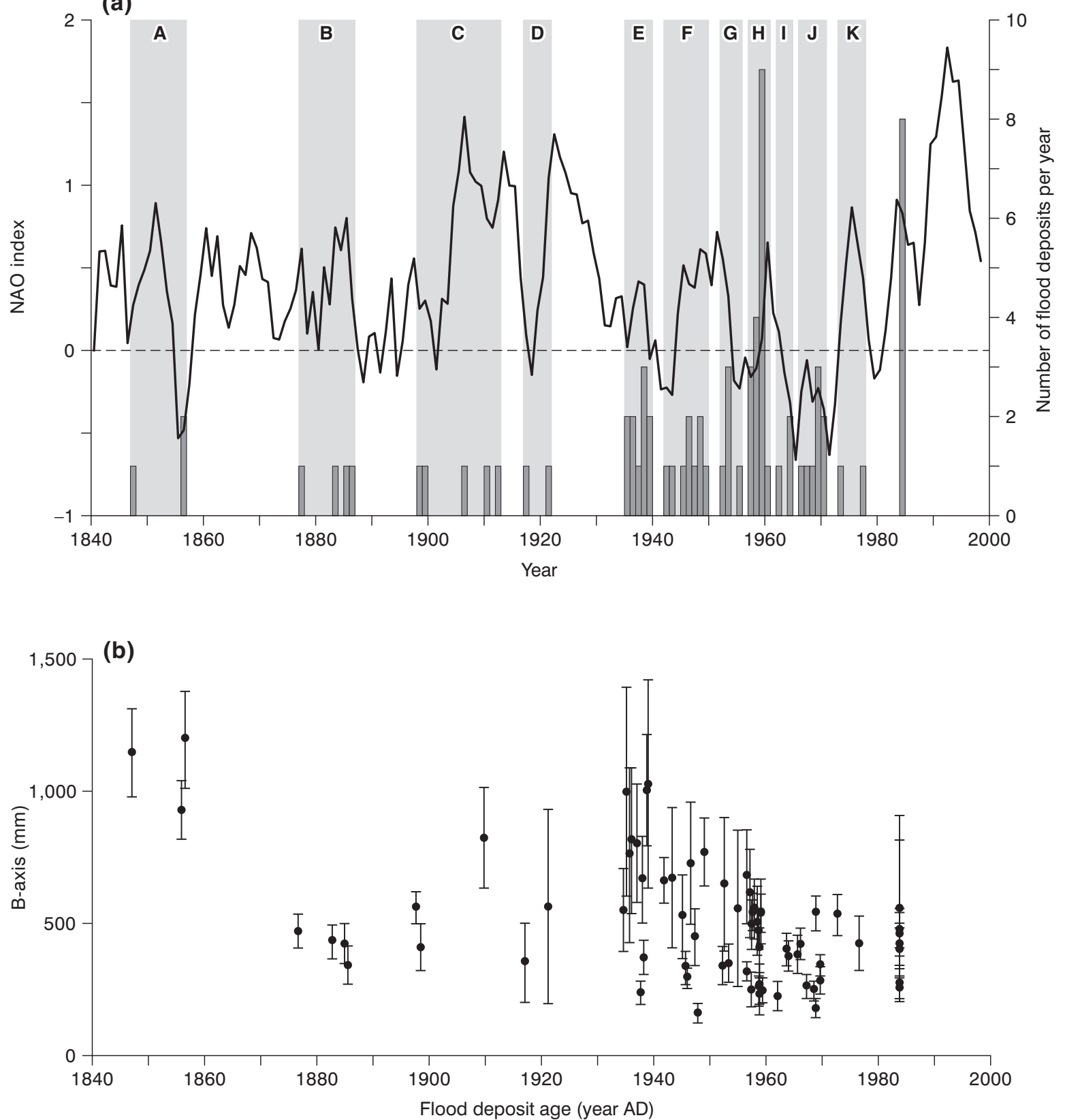

Fig. 11.17. The flood record for the Aradena Gorge in south-west Crete between 1840 and 2000 based on lichen dating of coarsegrained flood deposits. (a) The number of flood deposits per year compared with a five-year running mean of the winter (December to March) NAO index (1840-1996). The grey columns show the eleven age classes (A-K) identified from the lichen age data (see text for further discussion). (b) The mean size of the ten largest boulders from each dated flood unit. These data can be used as a proxy for flood magnitude with the largest boulders transported during the biggest floods. Boulder size is shown as the mean value and range of the ten largest boulders (modified from Maas and Macklin 2002). 
that boulder size may also be a function of sediment supply from hillslopes, and the decline in boulder size may partly reflect less effective slope channel coupling (Maas and Macklin 2002). Interestingly, the gauged record of daily rainfall from 1955 to 1987 also indicates a greater frequency of sustained high-intensity storms during negative phases of the winter NAO. This work shows a clear relationship between climate change, flood frequency and magnitude, and sediment supply for the past 150 years and this pattern has been recognized in several studies of coarse-grained flood deposits in river channel systems across the Mediterranean region (Hamlin et al. 2000; López-Aviléz 1999; Hewitt 2002; Noble 2004).

The historical flood record of the Rhône River provides valuable insights into the impact of the LIA on much larger-scale catchment dynamics. The Rhône drains a very large catchment $\left(97,800 \mathrm{~km}^{2}\right)$ that extends to the north of the Mediterranean zone of southern France. It provides a connection between the mountain catchments in the Alps-with their glacial and snowmelt regimes - and the Mediterranean lowlands and coastal zone of southern France where the floodplains and coastal zone have received large volumes of water and sediment during the course of the Pleistocene and Holocene. Glaciers expanded significantly in the Alps during the LIA (Grove 1988) and mass balance fluctuations impacted significantly on the Mediterranean region of the lower Rhône basin. From a detailed analysis of the historical flood record at the Arles gauging station between 1500 and 1995, Pichard (1995) has shown that the frequency of large floods decreased significantly after about 1860 . Large floods were defined as those that reached a stage $>5.25 \mathrm{~m}$ at Arles and this equates to a discharge of $>7,000 \mathrm{~m}^{3} \mathrm{~s}^{-1}$. These big floods were more frequent in the decades from 1651 to 1720 and 1751 to 1860 . This flood-dominated regime was interrupted by periods of low flood frequency from 1721 to 1750 and from 1861 to 1995 . The frequency of these large floods has fallen since the end of the LIA with eight to nine per decade between 1850 and 1900, four to five per decade between 1900 and 1950 and only two to three per decade between 1950 and 2000 (Pichard 1995; Arnoud-Fassetta 2003).

Further south in the western Mediterranean, Hewitt (2002) has developed a flood history for the Figarella River $\left(132 \mathrm{~km}^{2}\right)$ that drains to Calvi Bay from the mountains of north-west Corsica. Here, flood deposits-including boulder splays, boulder bars, and boulder berms-are well preserved across four terrace surfaces and these have also been dated using lichenometry. Hewitt (2002) identified 18 flood units that represent ten periods of enhanced flooding over the last four centuries, with the oldest units dated to between 1572 and 1595. Most of the flood units preserved in the Figarella record were deposited by floods that took place in the nineteenth century. In common with the record of large floods from the Rhône (Pichard 1995), the Figarella River has a much lower frequency of large floods in the twentieth in comparison to the nineteenth century. Hewitt (2002) has shown that the Figarella flood history shows a good agreement with the regional-scale record of large floods compiled from a range of data sources by Barriendos Vallve and Martin-Vide (1998) for ten river catchments that drain to the coast of north-east Spain (Figure 11.18). This figure compares flood records from documentary sources with geomorphological records from steep gradient river systems located in Corisca, Crete, and north-west Greece. Broadly speaking, five periods of enhanced flooding can be identified within these records:

1. The late sixteenth century (north-east Spain, southern France, and Corsica).

2. The late seventeenth to early eighteenth century (southern France).

3. Late eighteenth century (across the Mediterranean, but not in Crete).

4. The mid and late nineteenth century (across the Mediterranean).

5. The first half of the twentieth century (Corsica, north-west Greece, and Crete).

The record from north-west Greece is the only one in this data set to show enhanced flooding in the second half of the twentieth century. It is important to appreciate that the records from France and north-east Spain shown in Figure 11.18 come from documentary and instrumental sources, whilst those from Corsica, north-west Greece, and Crete are from geomorphological evidence dated by lichenometry and these three may partly reflect the influence of preservation factors. The Corsican record goes back as far as the longest historical records so far published for the western Mediterranean.

\section{Recent Human Modifications to River Channel Systems}

Over the last one hundred and fifty years or so, and especially since the Second World War, river channel systems in the Mediterranean region have been subjected to a range of modifications resulting from engineering works and resource exploitation. Impacts include 


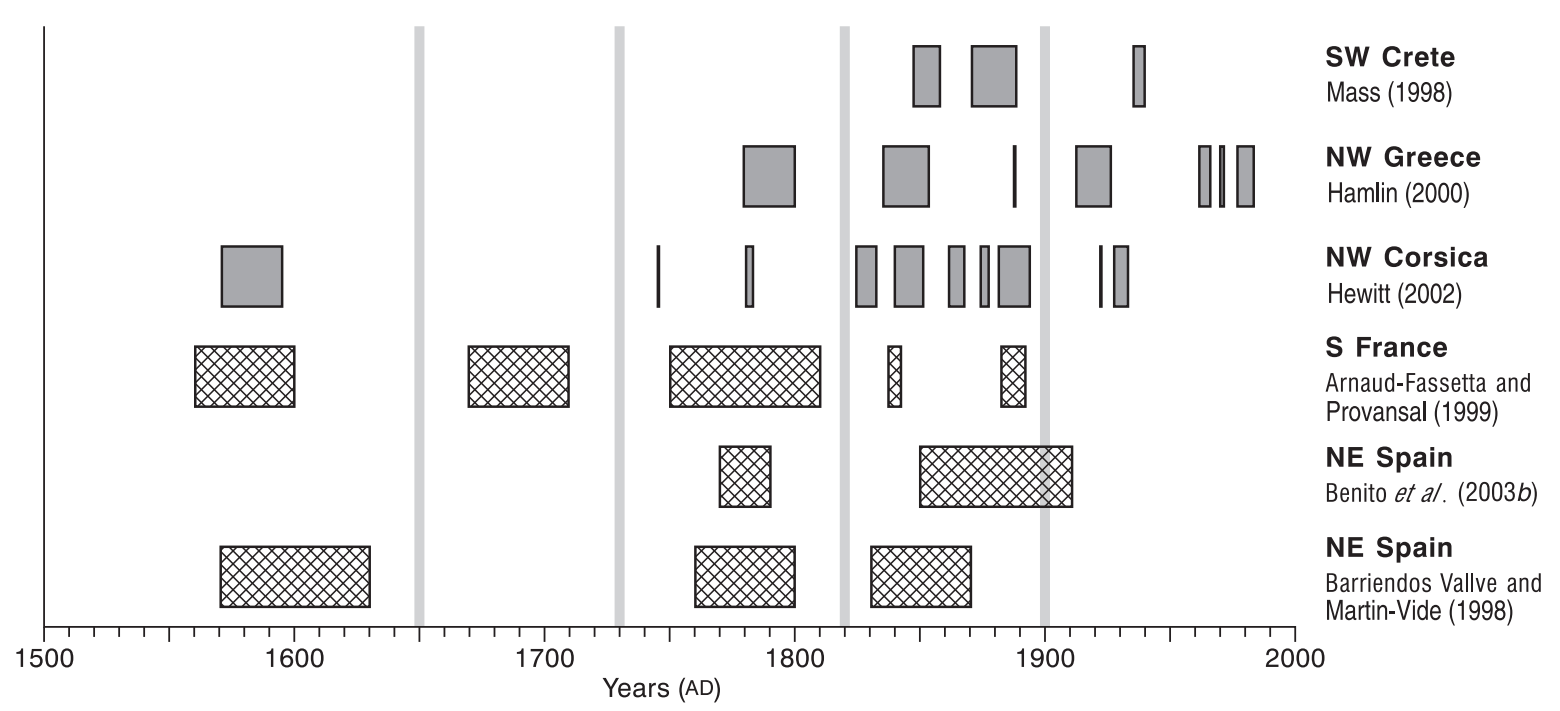

Fig. 11.18. Flood histories from five parts of the Mediterranean since AD 1500 based on geomorphological (solid shading) and documentary (hatched shading) records.

dam construction and reservoir development for hydroelectric power generation and flood control, as well as water resource development for irrigation and public water supply (Palanques et al. 1990; Surian 1999; Arnaud-Fassetta 2003). Reservoir sedimentation is now a major problem across the region (Lahlou 1988; Woodward 1995; Woodward and Foster 1997; Chapter 8) and this has led to river channel incision in downstream reaches (Surian and Rinaldi 2003).

In the middle and lower reaches of many river catchments, engineers have drained wetlands, built flood embankments, straightened channels, and developed extensive water abstraction and irrigation schemes. The second half of the twentieth century has seen an increasing demand for sands and gravels for a range of civil engineering projects including road building and urban development. This has encouraged intensive gravel extraction from floodplains and from the active channel zone in many Mediterranean rivers (Nicholas et al. 1999). The response of several Italian rivers to river engineering projects and gravel extraction has been reviewed by Surian and Rinaldi (2003). They have shown that $3-4 \mathrm{~m}$ of channel incision is a common response in reaches of the Po, Arno, and Piave rivers and channel narrowing of more than 50 per cent has been observed. These channel responses are more rapid immediately following the disturbances and the larger rivers tend to have longer recovery times. Surian and Rinaldi (2003) propose a model for the main styles of river channel response to recent human intervention in Italy with braided rivers adjusting through narrowing of the active channel zone with varying rates of incision, whereas single-thread river channels adjust via more pronounced vertical incision with variable degrees of channel narrowing.

Precious and base metal mining in the Mediterranean has a very long history with mining activity in the Río Tinto of south-west Spain being amongst the oldest in Europe dating back more than 5,000 years. Historical mining activity has resulted in significant and widespread contamination in many Mediterranean river basins with floodplain sediment in mining-affected catchments presently acting as a major secondary source of pollution (Macklin et al. 2006b). Environmental problems also arise from present-day mining activities with the April 1998 Aznalcóllar tailings dam failure being one of the most serious river pollution incidents in Europe since the Second World War (HudsonEdwards et al. 2003; Macklin et al. 2006b; Turner et al. 2002, 2008; Turner 2004). On 25 April 1998, a tailings dam failed at the Frailes lead and zinc mine at Aznalcóllar near Seville in south-west Spain. The spill released over 4 million $\mathrm{m}^{3}$ of toxic slurries into the Río Agrio, a tributary of the Río Guadiamar. This accident covered several thousand hectares of farmland with contaminated water and sediment and has had a long-lasting impact on the Río Guadiamar that received most of the tailings waste and 


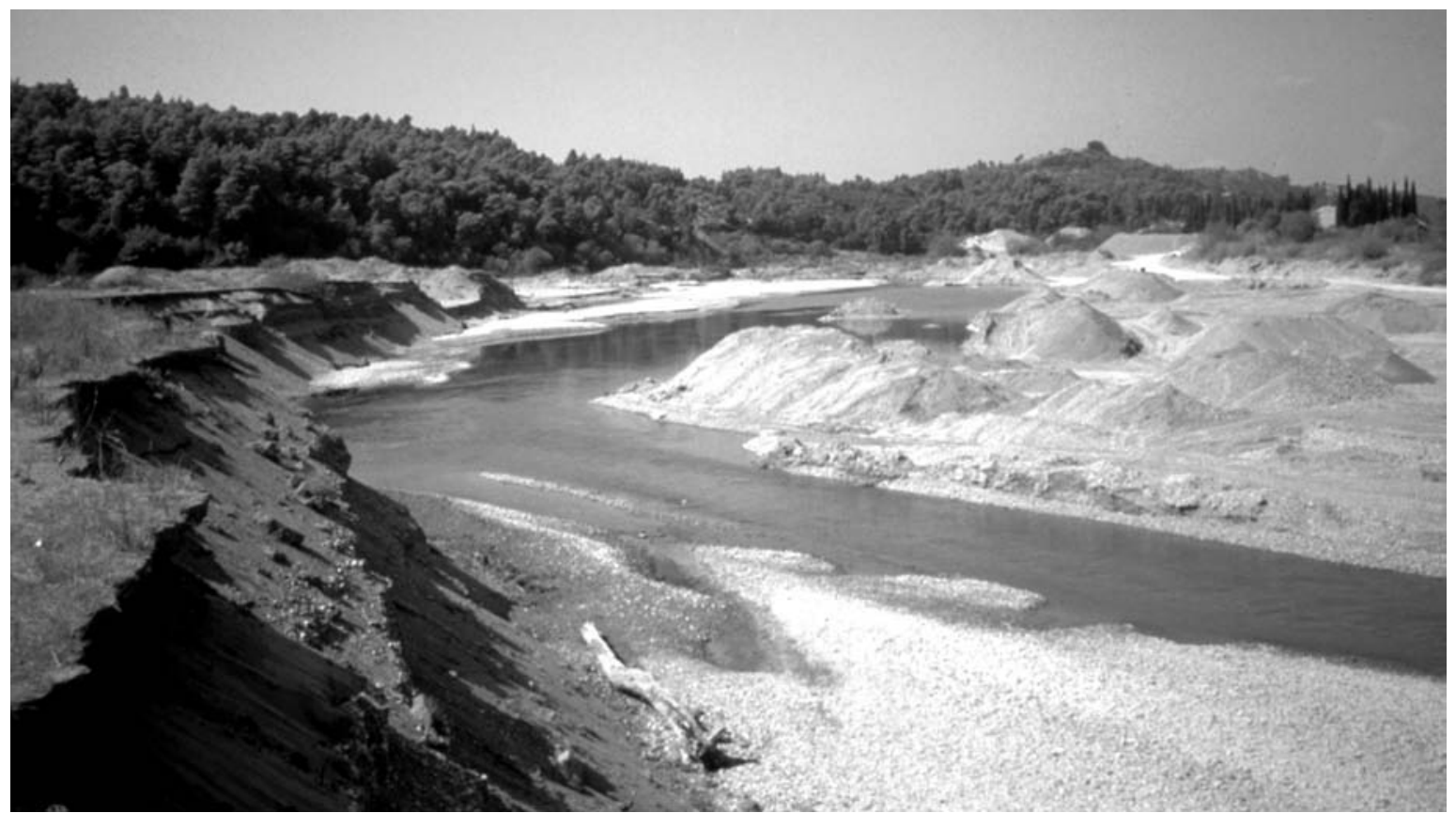

Fig. 11.19. The deeply incised channel zone of the Alfíos River in western Greece. Intensive in-stream gravel extraction has produced rapid channel degradation and bank retreat (photo: Jamie Woodward).

the internationally important wetlands of the Doñana National Park on the Atlantic coast (see Chapter 9). This UN World Heritage Area is still receiving significantly elevated concentrations of heavy metals ten years after the spill. Sediment-borne metals derived from the erosion and remobilization of contaminated river channel and floodplain sediment is the major problem at this site.

During the course of the twentieth century, the sediment load reaching the Rhône delta declined by a factor of 4.7 from 35 to 7.39 million tonnes per year largely due to the construction of large dams in the catchment. Channel incision on the Rhône delta began in 1895 , eventually leading to a lowering of the floodplain water table and salinization of floodplain soils as saline waters migrated upstream from the coastal zone (Arnaud-Fassetta 2003).

In western Greece, the lower reaches of the Alfios River basin $\left(3,600 \mathrm{~km}^{2}\right)$ were transformed in less than three decades following intensive gravel extraction from the bed of the active channel (Figure 11.19). Between 1967 and 1995 more than 17 million $\mathrm{m}^{3}$ of gravel were extracted using large cranes and drag buckets (Christopoulos 1998; Nicholas et al. 1999). This activity took place in the reaches immediately downstream of the Flokas Dam which is only about $5 \mathrm{~km}$ downstream of the archaeological site of Olympia - where this chapter began! The dam prevents bed load replenishment in the reaches downstream and this amplified the response of the channel to a major perturbation to the coarse sediment budget. This led to a period of rapid and sustained channel degradation resulting in $6-8 \mathrm{~m}$ of vertical incision and mean annual bank erosion rates of about $10 \mathrm{~m}$ per year with major bank failures associated with large flood events. Air photographs show that, in the gravel extraction reaches (immediately downstream of the Flokas Dam), the main channel of the Alfios River may have widened by up to $100 \mathrm{~m}$ between 1960 and 1990 (Christopoulos 1998; Nicholas et al. 1999).

Alluvial gravel extraction is common throughout the Mediterranean region where gravel bed rivers with broad channel zones and seasonally low stages provide ready access to this important resource. The regulation of these gravel extraction activities is commonly ineffective and excessive rates of extraction can promote rapid channel changes that may propagate both upstream and downstream. This has led to falling water tables, elevated turbidity, and large tracts of valley floor with severely degraded channel and riparian habitats. 


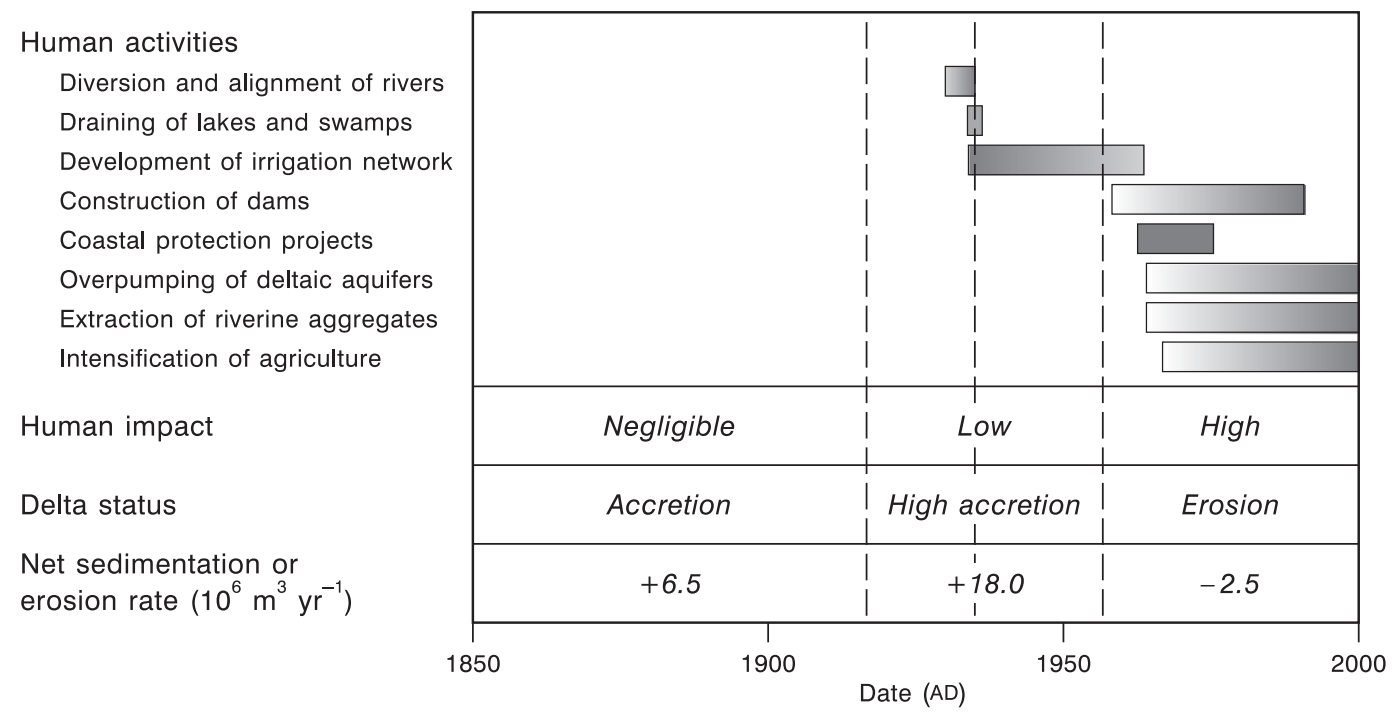

Fig. 11.20. Summary of human impacts on the river channel systems in the lower reaches and delta complex of the Axíos, Aliakmon, and Gallikos rivers in north-east Greece over the last century (modified from Kapsimalis et al. 2005). The darker the bars the greater the intensity of the human impact.

Fish species that spawn in gravel substrates are also threatened by gravel extraction. Cote et al. (1999) have shown how populations of river blennies (Salaria fluviatilis), that have a wide circum-Mediterranean distribution, are threatened by gravel extraction because structural alterations to gravel beds render the habitats unsuitable for breeding.

In north-east Greece, Kapsimalis et al. (2005) have investigated recent changes in the lower reaches of three large rivers systems that drain to the Inner Thermaikos Gulf in the north-west Aegean Sea. The catchments of the Axios $\left(23,747 \mathrm{~km}^{2}\right)$, Aliakmon $\left(9,250 \mathrm{~km}^{2}\right)$, and Gallikos $\left(1,230 \mathrm{~km}^{2}\right)$ rivers accounted for a mean annual water discharge of approximately $276 \mathrm{~m}^{3} \mathrm{~s}^{-1}$ between 1926 and 1970, but this has declined in recent years to $c .130 \mathrm{~m}^{3} \mathrm{~s}^{-1}$ because of abstractions for irrigation and urban consumption. Figure 11.20 provides a summary of the major changes between 1850 and 2000 to the lower reaches of these rivers following the increasing intensity of human impacts on water and sediment fluxes. The list of human activities shown in Figure 11.20 is typical of the impacts seen in many river basins across the Mediterranean region in the twentieth century (see Surian and Rinaldi 2003). These impacts have led to dramatic transformations to alluvial channels, floodplains, and deltaic environments. The net result of these activities has been a radical transformation of catchment water and sediment budgets and of channel and floodplain environments across the region and these impacts are especially apparent in the more populous European Mediterranean.

\section{Conclusions}

The Mediterranean basin provides a unique region in which to examine the long-term impact of environmental change on river system dynamics. The tectonic disposition of the region means that Quaternary fluvial sediments and landforms are commonly well preserved in river basins across the region and they represent a very significant archive of environmental change. The rich archaeological records have allowed humanriver environment interactions to be studied in unusual detail from Palaeolithic to recent times. The interaction between fluvial geomorphologists and archaeologists over many decades has generated important ideas and debates about river system development that have resonated well beyond the Mediterranean world. Recent advances include the development of much more robust dating frameworks for fluvial sequences and a greater appreciation of the significance of large floods in the creation of the fluvial archive. However, there is still much work to do if we are to resolve outstanding issues associated with the investigation and interpretation of the Holocene record. More detailed records 
of land use change are needed in many areas. Closer collaboration at the basin scale between geoscientists and archaeologists and historians would improve our understanding of the impacts of land use change on the behaviour of river basin systems.

The flood hydrology and sediment loads of many catchments across the Mediterranean were modified significantly by the climate changes associated with the Little Ice Age and data from this period provide a valuable guide for our interpretation of earlier parts of the fluvial archive. Researchers now have a much better appreciation of the role of large flood events in Mediterranean river systems through the systematic investigation of slackwater sediments, boulder flood units, documentary evidence, and the monitored hydrological record. Environmental changes associated with direct human impacts on river systems have intensified over the last 150 years or so and many valley floor environments in the Mediterranean have been degraded by resource exploitation, urban expansion, and the impacts of water and sediment pollution.

\section{Acknowledgements}

This chapter was completed in the Acropole Hotel in Khartoum about 3,000 km upstream of the Mediterranean Sea. We would like to thank the external reviewer for a thoughtful review of the text and Nick Scarle for producing the diagrams. Our work in the Mediterranean has been supported by various bodies over the last two decades including the NERC and by many interdisciplinary archaeological projects. It has also involved collaboration with several generations of Ph.D. students and with many colleagues and good friends. We are grateful to them all.

\section{References}

Abbott, J. T. and Valestro, S. (1995), The Holocene alluvial records of the chorai of Metapontum, Basilicata, and Croton, Calabria, Italy, in J. Lewin, M. G. Macklin, and J. C. Woodward (eds.), Mediterranean Quaternary River Environments. Balkema, Rotterdam, 195-205.

Allen, J. R. M., Brandt, U., Brauer, A., Hubberten, H. W., Huntley, B., Keller, J., Kraml, M., Mackensen, A., Mingram, J., Negendank, J. F. W., Nowaczyk, N. R., Oberhansli, H., Watts, W. A., Wulf, S., and Zolitschka, B. (1999), Rapid environmental changes in southern Europe during the last glacial period. Nature 400: 740-3.

Almagià, R. (1918), Trace glaciali nelle montagne dell'Albania. Rivista Geografica Italiana 25: 85-95.

Anketell, J. M., Ghellali, S. M., Gilbertson, D. D., and Hunt, C. O. (1995), Quaternary wadi and floodplain sequences of Tripolitania, northwest Libya: A synthesis of their stratigraphic relationships, and their implications in landscape evolution, in J. Lewin, M. G. Macklin, and J. C. Woodward (eds.), Mediterranean Quaternary River Environments. Balkema, Rotterdam, $231-44$.
Arnaud-Fassetta, G. and Provansal M., (1999), High frequency variations of water flux and sediment discharge during the Little Ice Age (1586-1725 AD) in the Rhône Delta (Mediterranean France). Relationship to the catchment basin. Hydrobiologia 410: 241-50.

- (2003), River channel changes in the Rhône Delta (France) since the end of the Little Ice Age: geomorphological adjustment to hydroclimatic change and natural resource management. Catena 51: 141-72.

Bailey, G. N. (ed.) (1997), Klithi: Palaeolithic Settlement and Quaternary Landscapes in Northwest Greece, i. Excavation and Intrasite Analysis at Klithi. McDonald Institute for Archaeological Research, Cambridge.

Lewin, J., Macklin, M. G., and Woodward, J. C. (1990), The 'Older Fill' of the Voidomatis Valley Northwest Greece and its relationship to the Palaeolithic Archaeology and Glacial History of the Region. Journal of Archaeological Science 17: 145-50.

Barriendos Vallve, M. and Martin-Vide, J. (1998), Secular Climatic Oscillations as Indicated by Catastrophic Floods in the Spanish Mediterranean Coastal Area (14th-19th Centuries). Climatic Change 38: 473-91.

Bavec, M., Tulaczyk, S. M., Mahan, S. A., and Stock, G. M. (2004), Late Quaternary glaciation of the upper Soča River region, southern Julian Alps, NW Slovenia. Sedimentary Geology 165: 265-83.

Benito, G. (2003), Palaeohydrological changes in the Mediterranean region during the Late Quaternary, in K. J. Gregory and G. Benito (eds.), Palaeohydrology: Understanding Global Change. John Wiley, Chichester, 123-42.

Sopeñab, A., Sánchez-Moyac, Y., Machadod, M. J., and Pérez-González, A. (2003a), Palaeoflood record of the Tagus River (Central Spain) during the Late Pleistocene and Holocene. Quaternary Science Reviews 22: 1737-56.

Díez-Herrero, A., and Fernández de Villalta, M. (2003b), Magnitude and frequency of flooding in the Tagus basin (central Spain) over the last millennium. Climatic Change 58: 171-92.

Bintliff, J. L. (1992), Erosion in the Mediterranean lands: A reconsideration of pattern, process and methodology, in M. G. Bell and J. Boardman (eds.), Past and Present Soil Erosion. Oxbow, Oxford, 125-31.

(2002), Time, process and catastrophism in the study of Mediterranean alluvial history: A review. World Archaeology 33: 417-35.

— and Snodgrass, A. M. (1985), The Cambridge/Bradford Boeotian Expedition: The first four years. Journal of Field Archaeology 12: 123-61.

Blissenbach, E. (1954), Geology of alluvial fans in semiarid regions. Geological Society of America Bulletin 65: 175-89.

Bond, G., Broecker, W., Johnsen, S., McManus, J., Labeyrie, L., Jouzel, J., and Bonani, G. (1993), Correlations between climate records from North Atlantic sediments and Greenland ice. Nature 365: 143-7.

Kromer, B., Beer, J., Muscheler, R., Evans, M. N., Showers, W., Hoffman, S., Lotti-Bond, R., Hajdas, I., and Bonani, G. (2001), Persistent solar influence on North Atlantic climate during the Holocene. Science 294: 2130-6.

Branca, S. and Ferrara, V. (2001), An example of river pattern evolution produced during the lateral growth of a central polygenic volcano: the case of the Alcantara river system, Mt Etna (Italy). Catena 45: 85-102. 
Brückner, H. (1986), Man's impact on the evolution of the physical environment in the Mediterranean region in historical times. GeoJournal 13: 7-17.

Butzer, K. W. (1969), Changes in the land. Science 165: 52-3.

Butzer, K. W. (1977), Geo-archaeology in practice. Reviews of Anthropology 4: 125-31.

- (1980), Holocene alluvial sequences: problems of dating and correlation, in R. A. Cullingford, D. A. Davidson, and J. Lewin (eds.), Timescales in Geomorphology. John Wiley \& Sons, Chichester, 131-42.

Candy, I., Black, S., and Sellwood, B. W. (2005), U-series isochron dating of immature and mature calcretes as a basis for constructing Quaternary landform chronologies for the Sorbas basin, southeast Spain. Quaternary Research 64: 100-1.

Carrión, J. S. (2002), Patterns and processes of Late Quaternary environmental change in a montane region of southwestern Europe. Quaternary Science Reviews 21: 2047-66.

Casford, J. S. L., Abu-Zied, R. H., Rohling, E. J., Cooke, S., Boessenkool, K. P., Brinkhuis, H., de Vries, C., Wefer, G., Geraga, M., Papatheodorou, G., Croudace, I., Thomson, J., Wells, N. C., and Lykousis, V. (2001), Mediterranean climate variability during the Holocene. Mediterranean Marine Science 2: 45-55.

Christopoulos, G. (1998), Late Holocene river behaviour in the lower Alfios basin, western Greece. Ph.D. Thesis, University of Leeds.

Cvijić, J. (1900), L’Époque Glaciaire dans la Péninsule des Balkans. Annales de Géographi 9: 359-72.

Collier, R. E. L., Leeder, M. R., and Jackson, J. A. (1995), Quaternary drainage development, sediment fluxes and extensional tectonics in Greece, in J. Lewin, M. G. Macklin, and J. C. Woodward (eds.), Mediterranean Quaternary River Environments. Balkema, Rotterdam, 31-44.

Conchon, O. (1986), Quaternary glaciations in Corsica. Quaternary Science Reviews 5: 429-32.

Cote, I. M., Vinyoles, D., Reynolds, J. D., Doadrio, I., and Perdices, A. (1999), Potential impacts of gravel extraction on Spanish populations of river blennies Salaria fluviatilis (Pisces, Blenniidae). Biological Conservation 87: 359-67.

Dansgaard, W., Johnsen, S. J., Clausen, H. B., Dahl-Jensen, D., Gundestrup, N. S., Hammer, C. U., Hvidberg, C. S., Steffensen, J. P., Sveinbjörnsdottir, A. E., Jouzel, J., and Bond, G. (1993), Evidence for general instability of past climate from a 250-kyr ice-core record. Nature 364: 218-20.

Davidson, D. A. and Shackley, M. R. (1976), Geoarchaeology: Earth Science and the Past. Duckworth, London.

Dewey, J. F., Pitman III, W. C., Ryan, W. B. F., and Bonnin, J. (1973), Plate tectonics and the evolution of the Alpine system. Geological Society of America Bulletin 84: 3137-80.

Fuller, I. C., Macklin, M. G., Passmore, D. G., Brewer, P. A., Lewin, J., and Wintle, A. G. (1996), Geochronologies and environmental records of Quaternary fluvial sequences in the Guadalope basin, northeast Spain, based on luminescence dating, in J. Branson, A. G. Brown, and K. J. Gregory (eds.), Global Continental Changes: the Context of Palaeohydrology. Geological Society of London Special Publication 115: 99-120.

(1998), River response to highfrequency climate oscillations in southern Europe over the past 200 k.y. Geology 26: 275-8.

Gamble, C. S. (1986), The Palaeolithic Settlement of Europe. Cambridge University Press, Cambridge.

Gaucher, G. (1947), Les dépôts quaternaires du Bas-Chélif et des basses plaines oranaises. CR Acad. Sci. Paris 225: 65-6.
Gigout, M. (1959), A propos du Quaternaire marin sur le litoral de la Provincia de Tarragona. Boletin. Com. Mapa. Geol. Tomo, IV Madrid.

Gilbertson, D. D., Hunt, C. O., and Smithson, P. A. (1996), Quaternary geomorphology and palaeoecology, in G. W. W. Barker, D. D. Gilbertson, G. D. B. Jones, and D. J. Mattingly (eds.), Farming the Desert: The UNESCO Libyan Valleys Archaeological Survey i: 49-82.

Greenbaum, N., Asher, P., Schick, A. P., and Baker, V. R. (2000) The palaeoflood record of a hyperarid catchment, Nahal Zin, Negev Desert, Israel. Earth Surface Processes and Landforms 25: 951-71.

- Porat, N., Rhodes, E., and Enzele, Y. (2006) Large floods during late Oxygen Isotope Stage 3, southern Negev desert, Israel. Quaternary Science Reviews 25: 704-19.

Griffiths, J. S., Mather, A. E., and Hart, A. B. (2002), Landslide susceptibility in the Río Aguas catchment, SE Spain. Quarterly Journal of Engineering Geology and Hydrogeology 35: 9-17.

Grove, A. T. (2001), The 'Little Ice Age' and its geomorphological consequences in Mediterranean Europe. Climatic Change 48: $121-36$.

Grove, J. M. (1988), The Little Ice Age. Routledge, London.

- and Conterio, A. (1995), The climate of Crete in the sixteenth and seventeenth centuries. Climatic Change 30: 223-47.

Hamlin, R. H. B. (2000), Environmental change and catastrophic flooding in the Voidomatis and Aoos Basins, Northwes t Greece. Ph.D. Thesis, University of Leeds.

Woodward, J. C., Black, S., and Macklin, M. G. (2000), Sediment fingerprinting as a tool for interpreting long-term river activity: the Voidomatis basin, NW Greece, in I. D. L. Foster (ed.), Tracers in Geomorphology. John Wiley \& Sons, Chichester, 473-501.

Harvey, A. M. and Wells, S. G. (1987), Response of Quaternary fluvial systems to differential epeirogenic uplift: Aguas and Feos river systems, southeast Spain. Geology 15: 689-93.

-Miller, S. Y., and Wells, S. G. (1995), Quaternary soil and river terrace sequences in the Aguas/Feos river systems: Sorbas basin, southeast Spain, in J. Lewin, M. G. Macklin, and J. C. Woodward (eds.), Mediterranean Quaternary River Environments. Balkema, Rotterdam, 263-81.

Hewitt, S. (2002), Pleistocene river behaviour and sediment transfer in glaciated catchments of the Mediterranean. Ph.D. Thesis, University of Leeds.

Hey, R. W. (1962), The Quaternary and Palaeolithic of Northern Libya, Quaternaria 6: 435-49.

Higgs, E. S. and Vita-Finzi, C. (1966), The Climate, Environment and Industries of Stone Age Greece: Part II. Proceedings of the Prehistoric Society 32: 1-29.

Hudson-Edwards, K. A., Macklin, M. G., Jamieson, H. E., Brewer, P. A., Coulthard, T. J., Howard, A. J., and Turner, J. N. (2003), The impact of tailings dam spills and clean-up operations on sediment and water quality in river systems: The Ríos Agrio-Guadiamar, Aznalcóllar, Spain. Applied Geochemistry 18: 221-39.

Hughes, P. D., Woodward, J. C., and Gibbard, P. L. (2006a), Glacial history of the Mediterranean mountains. Progress in Physical Geography 30: 334-64.

Macklin, M. G., Gilmour, M. A., and Smith, G. R. $(2006 b)$, The glacial history of the Pindus Mountains, Greece. Journal of Geology 114: 413-34.

Huntington, E. (1910), The Burial of Olympia. Geographical Journal 36: 657-86. 
Judson, S. (1963), Erosion and deposition of Italian stream valleys during historical time. Science 140: 898-9.

Kapsimalis, V., Poulos, S. E., Karageorgis, A. P., Pavlakis, P., and Collins, M. (2005), Recent evolution of a Mediterranean deltaic coastal zone: human impacts on the Inner Thermaikos Gulf, NW Aegean Sea. Journal of the Geological Society 162: 897-908.

Kelly, M., Black, S., and Rowan, J. S. (2000), A calcrete-based U/Th chronology for landform evolution in the Sorbas basin, Southeast Spain. Quaternary Science Reviews 19: 995-1010.

Kraft, J. C., Rapp, G., and Aschenbrenner, S. E. (1975), Holocene palaeogeography of the coastal plain of the Gulf of Messenia, Greece, and its relationship to archaeological setting and coastal change. Bulletin of the Geological Society of America 86: 1191-208.

— Kayan, I., and Erol, O. (1980), Geomorphic Reconstructions in the Environs of Ancient Troy. Science. 209: 776-82.

— Bruckner, H., Kayan, I., and Engelman, H. (2007), The geographies of Ancient Ephesus and the Artemision in Anatolia. Geoarchaeology: An International Journal 22: $121-49$.

Lahlou, A. (1988), The silting of Moroccan dams. In: M. P. Bordas and D. E. Walling (eds.), Sediment Budgets. IAHS Publication No. 174: 71-77.

Lewin, J. and Macklin, M. G. (2003), Preservation potential for Late Quaternary river alluvium. Journal of Quaternary Science 18: 107-20.

and Woodward, J. C. (1991), Late Ouaternary fluvial sedimentation in the Voidomatis Basin, Epirus, northwest Greece. Quaternary Research 35: 103-15.

(eds.) (1995), Mediterranean Quaternary River Environments. A. A. Balkema, Rotterdam.

López-Avilés, A. (1999), Flood regime and Quaternary sedimentation style in the Guadalope Basin, northeast Spain. Ph.D. Thesis University of Leeds.

- Ashworth, P. J., and Macklin, M. G. (1998), Floods and Quaternary sedimentation style in a bedrock-controlled reach of the Bergantes River, Ebro Basin, northeast Spain, in G. Benito, V. R. Baker, and K. J. Gregory (eds.), Palaeohydrology and Environmental Change. Wiley, Chichester, 181-96.

Lowe, J. J. and Walker, M. J. C. (1997), Reconstructing Quaternary Environments (2nd edn.). Addison-Wesley-Longman, London.

Maas, G. S. (1998), River response to Late Quaternary environmental change, southwestern Crete, Greece. Ph.D. thesis University of Leeds.

— and Macklin, M. G. (2002), The impact of recent climate change on flooding and sediment supply within a Mediterranean mountain catchment, southwestern Crete, Greece. Earth Surface Processes and Landforms 27: 1087-105.

McBurney, C. B. M. and Hey, R. W. (1955), Prehistory and Pleistocene Geology in Cyrenaican Libya. A Record of Two Seasons' Geological and Archaeological Fieldwork in the Gebel Akhdar Hills, with a Summary of Prehistoric Finds from Neighbouring Territories. Cambridge University Press, Cambridge.

Macklin, M. G. (1995), Geochronology, correlation and controls of Quaternary river erosion and sedimentation, in J. Lewin, M. G. Macklin, and J. C. Woodward (eds.), Mediterranean Quaternary River Environments. Balkema, Rotterdam, 179-81.

_ and Lewin, J. (2003), River sediments, great floods and centennial-scale Holocene climate change. Journal of Quaternary Science 18: 102-5.
— and Needham, S. (1992), Studies in alluvial archaeology: potential and prospect, in S. Needham and M. G. Macklin (eds.), Alluvial Archaeology in Britain. Oxbow, Oxford, 9-23.

— and Passmore, D. G. (1995), Pleistocene environmental change in the Guadalope basin, northeast Spain: fluvial and archaeological records, in J. Lewin, M. G. Macklin, and J. C. Woodward (eds.), Mediterranean Quaternary River Environments. Rotterdam, Balkema, 103-113.

Lewin, J., and Woodward, J. C. (1995), Quaternary fluvial systems in the Mediterranean basin, in J. Lewin, M. G. Macklin, and J. C. Woodward (eds.), Mediterranean Quaternary River Environments. Balkema, Rotterdam, 1-25.

- (1997), Quaternary River Sedimentary Sequences of the Voidomatis Basin, in G. N. Bailey (ed.), Klithi: Palaeolithic Settlement and Quaternary Landscapes in Northwest Greece, ii. Klithi in its Local and Regional Setting. McDonald Institute for Archaeological Research, Cambridge, 347-59.

Fuller, I. C., Lewin, J., Maas, G. S., Passmore, D. G., Rose, J., Woodward, J. C., Black, S., Hamlin, R. H. B., and Rowan, J. S. (2002), Correlation of Late and Middle Pleistocene fluvial sequences in the Mediterranean and their relationship to climate change. Quaternary Science Reviews 21: 1633-44.

- Johnstone, E., and Lewin, J. (2005), Pervasive and longterm forcing of Holocene river instability and flooding by centennial-scale climate change. The Holocene 15: 937-43.

- Benito, G., Gregory, K. J., Johnstone, E., Lewin, J., Michczyńska, D. J., Soja, R., Starkel, L., and Thorndycraft, V. R. (2006a), Past hydrological events reflected in the Holocene fluvial record of Europe. Catena 66: 145-54.

- Brewer, P. A., Hudson-Edwards, K. A., Bird, G., Coulthard, T. J., Dennis, I. A., Lechler, P. J., Miller, J. R., and Turner, J. N. (2006b), A geomorphological approach to the management of rivers contaminated by metal mining. Geomorphology 79 : $423-47$.

McManus, J. F., Anderson, R. F., Broecker, W. S., Fleisher, M. Q., and Higgins, S. M. (1998), Radiometrically determined sedimentary fluxes in the sub-polar North Atlantic during the last 140,000 years. Earth and Planetary Science Letters 155: 29-43.

Magny, M., Bégeot, C., Guiot, J., and Peyron, O. (2003), Contrasting patterns of hydrological changes in Europe in response to Holocene climate cooling phases. Quaternary Science Reviews 22: 1589-96.

Mather, A. E. (2000), Adjustment of a drainage network to capture induced base-level change. Geomorphology 34: 271-89.

- Harvey, A. M., and Brencheley, P. J. (1991), Halokinetic deformation of Quaternary river terraces in the Sorbas basin, SE Spain. Zeitfrich für Geomorphologie Suppl. 82: 87-97.

Moody, J. and Grove, A. T. (1990), Terraces and enclosure walls in the Cretan landscape, in S. Bottema, G. Entjes-Nieborg, and W. van Zeist (eds.), Man's Role in the Shaping of the Eastern Mediterranean Landscape. A. A. Balkema, Rotterdam, 183-91.

Nicholas, A. P., Woodward, J. C., Christopoulos, G., and Macklin, M. G. (1999), Modelling and monitoring the impact of dam construction and gravel extraction on rates of bank erosion in the Alfios River, Peloponnese, western Greece, in A. G. Brown and T. A. Quine (eds.), Fluvial Processes and Environmental Change. John Wiley \& Sons, Chichester, 117-37.

Niculescu, C. (1915), Sur les traces de glaciation dans le massif Smolica chaîne du Pinde méridional. Bulletin de la Section Scientifique de l'Academie Roumaine 3: 146-51. 
Noble, J. (2004), Response of a steepland river system to late Quaternary environmental change: south central Crete. Ph.D. Thesis, University of Wales, Aberystwyth.

Paepe, R., Hatziotis, M. E., and Thorez, J. (1980), Geomorphological Evolution in the Eastern. Mediterranean Belt and Mesopotamian Plain. Report for the International Geological Correlation Programme Project 146: River flood and lake level changes.

Palanques, A., Plana, F., and Maldonado, A. (1990), Recent influence of man on the Ebro margin sedimentation system, northwestern Mediterranean Sea. Marine Geology 95: 247-63.

Pichard, G. (1995), Les crues sur le bas Rhône de 1500 à nos jours. Pour une histoire hydro-climatique. Méditerranée 3/4: 105-16.

Piegay, H. and Bravard, J.-P. (1997), Response of a Mediterranean riparian forest to a 1 in 400 year flood, Ouveze River, Drome-Vaucluse, France. Earth Surface Processes and Landforms 22: 31-43.

Pope, K. O. and van Andel, T. H. (1984), Late Quaternary alluviation and soil formation in the southern Argolid: its history, causes and archaeological implications. Journal of Archaeological Science 11: 281-306.

Raphael, C. N. (1973), Late Quaternary Changes in Coastal Elis, Greece. Geographical Review 63: 73-89.

Renfrew, A. C. and Wagstaff, M. (1982), An Island Polity: The Archaeology of Exploitation in Melos. Cambridge University Press, Cambridge.

Roberts, N., Reed, J., Leng, M. J., Kuzucuoğlu, C., Fontugne, M., Bertaux, J., Woldring, H., Bottema, S., Black, S., Hunt, E., and Karabiylkoğlu, M. (2001), The tempo of Holocene climatic change in the eastern Mediterranean region: new highresolution crater-lake sediment data from central Turkey. The Holocene 11: 721-36.

Rose, J. and Meng, X. (1999), River activity in small catchments over the last $140 \mathrm{ka}$, northeast Mallorca, Spain, in: A. G. Brown and T. A. Quine (eds.), Fluvial Processes and Environmental Change. Wiley, Chichester, 91-102.

Roucoux, K. H., de Abreu, L., Shackleton, N. J., Tzedakis, P. C., (2005), The response of NW Iberian vegetation to North Atlantic climate oscillations during the last $65 \mathrm{kyr}$. Quaternary Science Reviews 25: 1637-53.

Rowan, J. S., Black, S., Macklin, M. G., Tabner, B. J., and Dore, J. (2000), Quaternary environmental change in Cyrenaica evidenced by U-Th, ESR and OSL of coastal alluvial fan sequences. Libyan Studies 31: 5-16.

Rumsby, B. A. and Macklin, M. G. (1996), River response to the last neoglacial (the 'Little Ice Age') in northern, western and central Europe, in K. J. Gregory (ed.), Global Continental Changes: The Context of Palaeohydrology. Geological Society Special Publication, London 115: 217-33.

Sadori, L. (2001), The Postglacial record of environmental history from Lago di Pergusa, Sicily. The Holocene 11: 655-71.

Sancho, C., Peña Monné, J. L., Lewis, C., McDonald, E., and Rhodes, E. (2003), Preliminary dating of glacial and fluvial deposits in the Cinca River Valley (NE Spain): chronological evidences for the Glacial Maximum in the Pyrenees? in B. Ruíz-Zapata, M. Dorado-Valiño, A. Valdemillos, M. J. Gil-García, T. Badají, I. Bustamante, I. Mendizábal (eds.), Quaternary Climatic Changes and Environmental Crises in the Mediterranean Region. Universidad de Alcalá de Henares, Madrid, 453-6.

Santisteban, J. I. and Schulte, L. (2007), Fluvial networks of the Iberian Peninsula: a chronological framework. Quaternary Science Reviews 26: 2738-57.
Schulte, L., Julià, R., Burjachs, F., and Hilgers, A. (2007), Middle Pleistocene to Holocene geochronology of the River Aguas terrace sequence (Iberian Peninsula): fluvial response to Mediterranean environmental change. Geomorphology 98: 13-33.

Selli, R. (1962), Le Quaternaire marin du versant Adriatique Ionien de la péninsule italienne. Quaternaria 6: 391-413.

Surian, N. (1999), Channel changes due to river regulation: the case of the Piave River, Italy. Earth Surface Processes and Landforms 24: 1135-51.

- and Rinaldi, M. (2003), Morphological response to river engineering and management in alluvial channels in Italy. Geomorphology 50: 307-26.

Thorndycraft, V. R. and Benito, G. (2006), Late Holocene fluvial chronology of Spain: The role of climatic variability and human impact. Catena 66: 34-41.

Turner, J. N. (2004), Ageomorphological-geochemical assessment of the impacts of the April 1998 Aznalcóllar tailings dam failure on the Rio Guadiamar, southwest Spain. Ph.D. Thesis, University of Wales, Aberystwyth.

- Brewer, P., Macklin, M. G., Hudson-Edwards, K. A., Coulthard, T. J., Howard, A. J., and Jamieson, H. E. (2002), Heavy metal and as transport under low and high flows in the River Guadiamar three years after the Aznalcollar tailings dam failure: Implications for river recovery and management, in J. M. Garcia, J. A. A. Jones, and J. Arnaez (eds.), Environmental Change and Water Sustainability. IPE-CSIC, Zaragoza, 235-51.

(2008) Fluvial-controlled metal and as mobilisation, dispersal and storage in the Río Guadiamar, SW Spain and its implications for long-term contaminant fluxes to the Doñana wetlands. Science of The Total Environment 394: 14461.

Tzedakis, P. C., Lawson, I. T., Frogley, M. R., Hewitt, G. M., and Preece, R. C. (2002), Buffered tree population changes in a Quaternary refugium: evolutionary implications. Science 297: 2044-7.

van Andel, T. H. and Runnels, C. (1987), Beyond the Acropolis: A Rural Greek Past. Cambridge University Press, Cambridge.

Runnels, C. N., and Pope, K. O. (1986), Five thousand years of land use and abuse in the southern Argolid. Hesperia 55: 103-28.

_Zangger, E., and Demitrack, A. (1990), Land use and soil erosion in Prehistoric and Historical Greece. Journal of Field Archaeology 17: 379-96.

Vita-Finzi, C. (1969), The Mediterranean Valleys: Geological Changes in Historical Times. Cambridge University Press, Cambridge.

(1976), Diachronism in Old World alluvial sequences. Nature 263: 218-19.

- (1986), Recent Earth Movements: An Introduction to Neotectonics. Academic Press, London.

Westaway, R., Pringle, M., Yurtmen, S., Demir, T., Bridgland, D., Rowbotham, G., and Maddy, D. (2003), Pliocene and Quaternary surface uplift of western Turkey revealed by long-term river terrace sequences. Current Science 84: 1090-101.

(2004), Pliocene and Quaternary regional uplift in western Turkey: the Gediz River terrace staircase and the volcanism at Kula. Tectonophysics 391: 121-69. 
Woodward, J. C. (1995), Patterns of erosion and suspended sediment yield in Mediterranean river basins, in I. D. L. Foster, A. M. Gurnell, and B. W. Webb (eds.), Sediment and Water Quality in River Catchments. John Wiley \& Sons Chichester, 365-89.

— and Foster, I. D. L. (1997), Erosion and suspended sediment transfer in river catchments: environmental controls, processes and problems. Geography 82/4: 353-76.

Lewin, J., and Macklin, M. G. (1992), Alluvial sediment sources in a glaciated catchment: the Voidomatis basin, northwest Greece. Earth Surface Processes and Landforms 16: 205-16.

- Macklin, M. G., and Lewin. J. (1994), Pedogenic weathering and relative age dating of Quaternary alluvial sediments in the Pindus Mountains of northwest Greece, in D. A. Robinson and R. B. G. Williams (eds.), Rock Weathering and Landform Evolution. John Wiley \& Sons, Chichester, 259-83.

Lewin, J., and Macklin, M. G. (1995), Glaciation, river behaviour and the Palaeolithic settlement of upland northwest Greece, in J. Lewin, M. G. Macklin, and J. C. Woodward (eds.), Mediterranean Quaternary River Environments. Balkema, Rotterdam, 115-29.
- Hamlin, R. H. B., Macklin, M. G., Karkanas, P., and Kotjabopoulou, E. (2001), Quantitative sourcing of slackwater deposits at Boila Rockshelter: A record of Lateglacial flooding and Palaeolithic settlement in the Pindus Mountains, Northwest Greece. Geoarchaeology: An International Journal 16: 501-36.

- Macklin, M. G., and Smith, G. R. (2004), Pleistocene glaciation in the mountains of Greece, in J. Ehlers and P. L. Gibbard (eds.), Quaternary Glaciations-Extent and Chronology: Part 1. Elsevier, Amsterdam, 155-73.

-Hamlin, R. H. B., Macklin, M. G., Hughes, P. D., and Lewin, J. (2008), Glacial activity and catchment dynamics in northwest Greece: Long-term river behaviour and the slackwater sediment record for the last glacial to interglacial transition. Geomorphology 101: 44-67.

Zielhofer, C., Faust, D., Baena Escudero, R., Diaz del Olmo, F., Kadereit, A., Moldenhauer, K., and Porras, A. (2004), Centennial-scale Late Pleistocene to mid-Holocene synthetic profile of the Medjerda Valley, northern Tunisia. The Holocene 14: 851-61.

Zorzou, M. (2004), Suspended sediment delivery and sediment properties in mountain catchments of western Greece. Ph.D. thesis, University of Leeds.

\section{This chapter should be cited as follows}

Macklin, M. G. and Woodward, J. C. (2009) River systems and environmental change, in J. C. Woodward (ed.), The Physical Geography of the Mediterranean. Oxford University Press, Oxford, 319-352. 